\title{
RIOLITAS DEL \\ ALTO LOS CACAOS
}

\Cordillera Oriental

Departamento de Santander

Ana María Correa Martínez, Gabriel Rodríguez, José Gilberto Bermúdez, María Isabel Arango y Gilberto Zapata

Catálogo de las unidades litoestratigráficas de Colombia / Triásico - Jurásico

Citación: Correa Martínez, A. M., Rodríguez, G., Bermúdez, J. G., Arango, M. I. y Zapata, G. (2020). Riolitas del Alto Los Cacaos. En Catálogos de las unidades litoestratigráficas de Colombia: Macizo de Santander. Vol. 1. Servicio Geológico Colombiano. https://doi.org/10.32685/9789585279445.9 
La actividad magmática del período Triásico tardío-Jurásico temprano en el Macizo de Santander está representada por cuerpos intrusivos graníticos e hipoabisales (Goldsmith et al., 1971; Ward et al., 1973) emplazados en un basamento metamórfico, una de cuyas partes inicialmente se interpretó como del Precámbrico (Restrepo et al., 1997; Cordani et al., 2005), y otra, del Paleozoico (Ward et al., 1973), si bien en los últimos años se ha reinterpretado todo como originado en el Paleozoico (Van der Lelij et al., 2016). Los estudios del magmatismo triásico-jurásico del Macizo de Santander se han enfocado en los grandes plutones (Ward et al., 1973, Van der Lelij, 2013; Van der Lelij et al., 2016), mientras que los cuerpos volcánicos han sido poco mencionados.

Durante la ejecución del proyecto Magmatismo Jurásico en Colombia en el Macizo de Santander, desarrollado por el Grupo de Estudios Geológicos Especiales de la regional Medellín del Servicio Geológico Colombiano, hacia la parte sursuroccidental del Batolito de Mogotes se estudió un cuerpo riolítico (Riolitas del Alto Los Cacaos) y se hallaron dos cuerpos riolíticos-riodacíticos (Riolita de San Joaquín y Riolitas de EI Uvo). El primero corresponde al objeto de este catálogo, y fue descrito por Ward et al. (1973) y cartografiado por Ward et al. (1977) como continuación, al sur, del Granito de Pescadero.

El objetivo del presente catálogo es mostrar las Riolitas del Alto Los Cacaos como una unidad litoestratigráfica nueva en la bibliografía de la geología colombiana y aportar al conocimiento geológico del Macizo de Santander. En el documento se presentan descripciones generales de campo, análisis petrográficos y de química mineral, resultados litogeoquímicos y edades radiométricas $\mathrm{U} / \mathrm{Pb}$ en circón de este cuerpo.

\section{Proponente del nombre}

El nombre Riolitas del Alto Los Cacaos es propuesto por los autores del presente trabajo. Atendiendo a las recomendaciones de la International Subcommission on Stratigraphic Classification de la IUGS $(1987,1994)$, se propone utilizar la denominación Riolitas del Alto Los Cacaos, en consideración a su litología dominante y al nombre geográfico de la localidad tipo.

\section{Origen del nombre y distribución geográfica}

\subsection{Origen del nombre}

El componente geográfico del nombre de la unidad proviene del Alto Los Cacaos, que es un sector atravesado por la carretera Mogotes-San Joaquín (figura 1), donde hay buenos afloramientos de esta unidad y se considera la localidad tipo.

\subsection{Distribución geográfica}

La unidad Riolitas del Alto Los Cacaos aflora en el departamento de Santander, al NW de la cabecera municipal del municipio de San Joaquín, donde ocupa un área aproximada de $22 \mathrm{~km}^{2}$.

Los afloramientos se encuentran desde el sector de San Antonio, pasando por Puente Tierra y el Alto Los Cacaos, hasta las proximidades de la cabecera municipal de San Joaquín.

\section{Reseña histórica}

La primera referencia escrita a este cuerpo hipoabisal fue realizada por Ward et al. (1973), que lo presentaron como una parte del Granito de Pescadero. Vargas et al. (1976) mencionan una intrusión pequeña de la riolita de Onzaga en los alrededores de San Joaquín, que debe corresponder al cuerpo de riolitas objeto de este trabajo. Por otro lado, la primera cartografía del cuerpo se halla en el mapa de Ward et al. (1977), donde también aparece representado con la nomenclatura de Granito de Pescadero, ubicado en el extremo suroccidental del Batolito de Mogotes. En mapas posteriores, como la Plancha 136, Málaga, a escala 1:100.000, de Vargas et al. (1984), este cuerpo no fue representado, y en su lugar aparece el área respectiva cartografiada como JRcm (cuarzomonzonita biotítica blanca a rosada, grano medio, alaskítica) dentro de una unidad mayor denominada Granito de Pescadero (Vargas et al., 1984). 

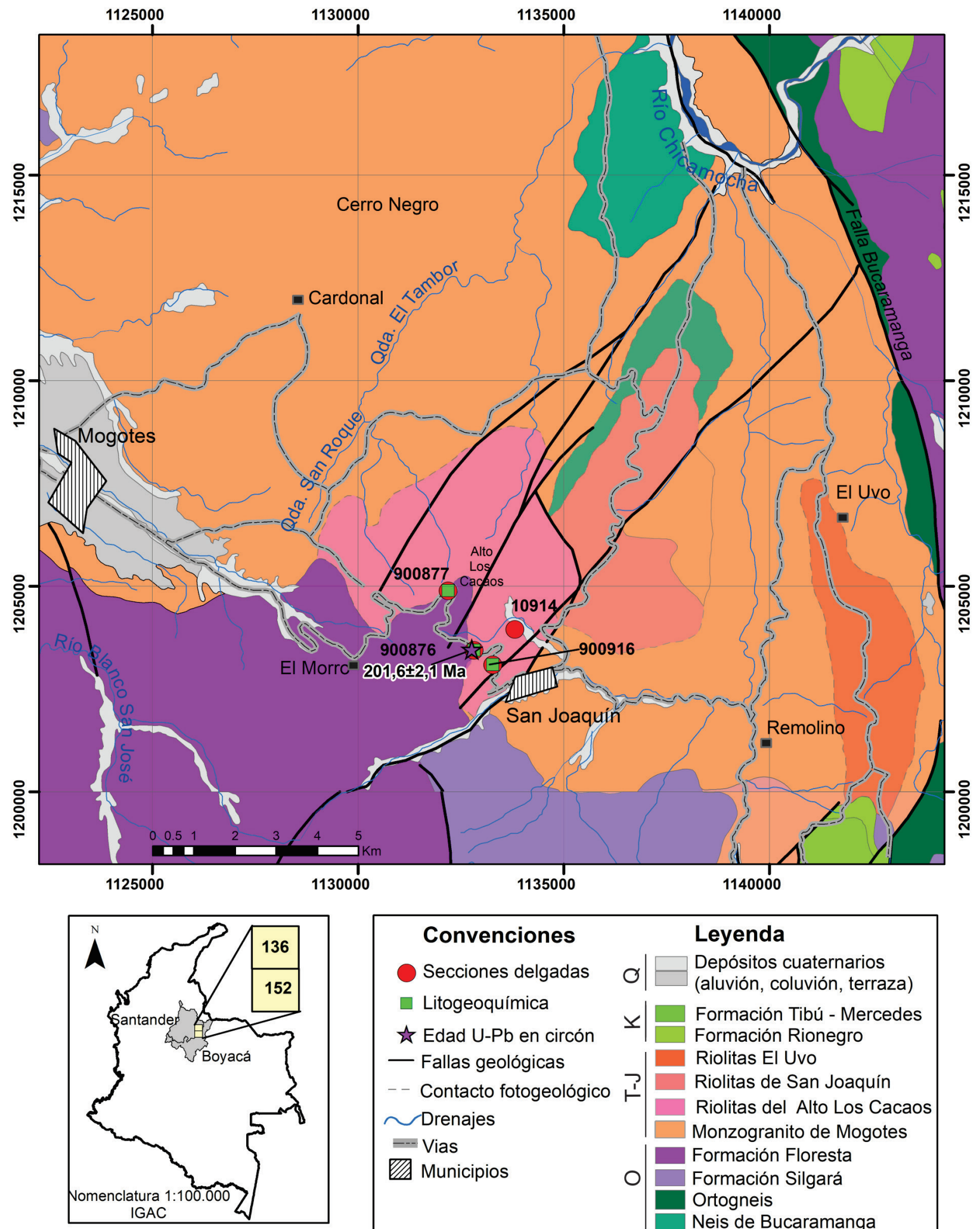

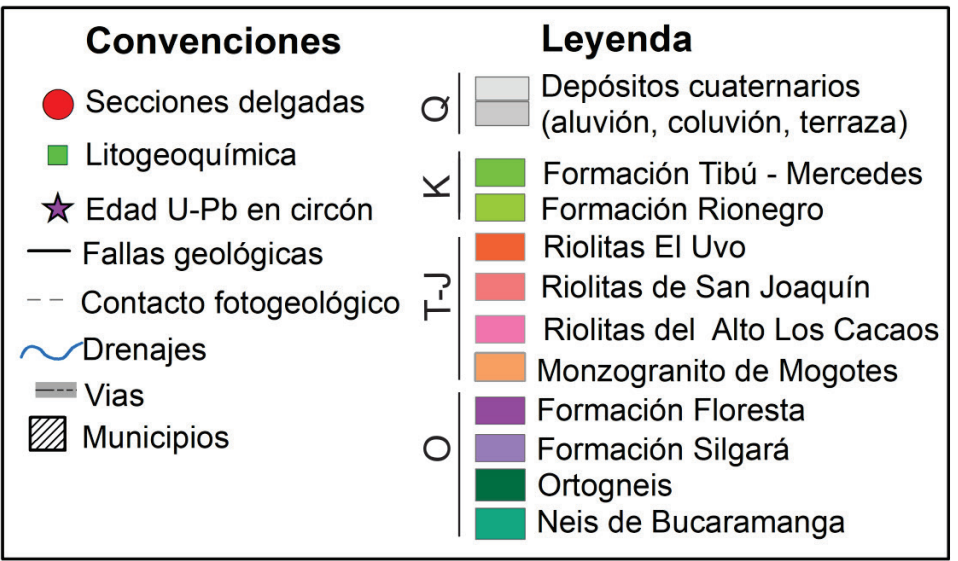

Figura 1. Mapa geológico regional con la localización de las Riolitas del Alto Los Cacaos y de las muestras analizadas. O: Ordovícico. T-J: Triásico tardío-Jurásico temprano. K: Cretácico. Q: Cuaternario

Fuente: cartografía modificada a partir de Ward et al. (1977) y Vargas et al. (1984), con datos de este trabajo 


\section{Descripción geológica}

\subsection{Marco geológico}

El Macizo de Santander forma parte de un bloque regional de forma triangular formado por las fallas de Santa Marta-Bucaramanga, en el lado occidental, la falla de Oca-Ancón, en el lado norte, y la falla de Boconó, en el lado oriental.

En términos de terrenos, la geología de esta región se ha incluido en el Terreno Chibcha (Restrepo y Toussaint, 1989) o en el Terreno Santander (Etayo Serna et al., 1985).

Las rocas del basamento del Macizo de Santander corresponden a unidades metamórficas, como el Neis de Bucaramanga (Ward et al., 1973), la Formación Silgará (Ward et al., 1973) o Esquistos de Silgará (Urueña, 2014) y el Ortoneis (Ward et al., 1973), cubiertas de manera discordante por rocas sedimentarias de la Formación Floresta, del Devónico.

El Neis de Bucaramanga, denominado también Complejo Bucaramanga (Clavijo, 1994), consiste en neises cuarzo-feldespáticos con andalucita, sillimanita, cordierita y granate, con intercalaciones de neis hornbléndico, anfibolita, mármol y migmatita (Ward et al., 1973), metamorfizados en la facies anfibolita alta. La unidad está cubierta por la Formación Silgará, aunque las relaciones entre ambas unidades no son totalmente claras (Ward et al., 1973, Restrepo Pace, 1995). Esta unidad se había interpretado tradicionalmente como del Proterozoico (Goldsmith et al., 1971; Ward et al., 1973; Restrepo Pace et al., 1997; García y Ríos, 1999; Cardona, 2003 y Cordani et al., 2005); sin embargo, los resultados geocronológicos obtenidos por Van der Lelij (2013) y en este proyecto indican edades en el Neis de Bucaramanga de ca. $465 \mathrm{Ma}$, que corresponde, al Ordovícico.

La Formación Silgará (Ward et al., 1973) está compuesta por esquistos, filitas, metalodolitas, metaareniscas ortoanfibolitas y escasos mármoles (Ward et al., 1973; García y Ríos, 1999; Ríos et al., 2003; Mantilla et al., 2013). Las rocas fueron metamorfizadas en la facies esquisto verde a anfibolita baja, aunque localmente hay indicios de anfibolita alta (Ward et al., 1973; Schäfer et al., 1998). La Formación Silgará presenta edades de metamorfismo del Ordovícico inferior a medio relacionadas con la orogenia Caledoniana (Forero, 1990; Ríos et al., 2003; Ordóñez et al., 2006; Clavijo et al., 2008; Mantilla et al., 2013).
El Ortoneis consiste en neises cuarzo-feldespáticos que varían en composición desde granito hasta tonalita (Ward et al., 1973), con lentes de anfibolita. En muchos lugares exhibe concordancia con estructuras del Neis de Bucaramanga y de la Formación Silgará (Ward et al., 1973). Son rocas de medio a alto grado de metamorfismo, de edad pre-Devónico Inferior-Ordovícico (Ward et al., 1973). Hay varios resultados geocronológicos que indican una edad ordovícica (Mantilla et al., 2012; Van der Lelij, 2013).

Hay evidencias geocronológicas, por edades $\mathrm{U} / \mathrm{Pb}$ en circón, de magmatismo posterior al metamorfismo, representado por metavulcanitas y plutones que intruyen el basamento metamórfico. Estas tienen edades del Silúrico, Devónico inferior, Carbonífero y límite Triásico-Jurásico (Goldsmith et al., 1971; Mantilla et al., 201 2; Van der Lelij, 2013, y este proyecto).

Durante el límite Triásico-Jurásico se desarrolló un importante magmatismo de arco, con el emplazamiento dentro del basamento metamórfico de grandes batolitos, stocks graníticos y cuerpos riolíticos subvolcánicos, localizados hacia la margen occidental del Macizo de Santander (Goldsmith et al., 1971; Ward et al., 1973; Van der Lelij, 2013, y este proyecto). La Riolita del Alto Los Cacaos es uno de los cuerpos subvolcánicos que se generó durante dicho magmatismo.

Sobre el basamento metamórfico y los plutones se encuentran de manera discordante unidades sedimentarias cretácicas y, finalmente, pórfidos del Mioceno mineralizados con oro (Leal Mejía, 201 1; Mantilla et al., 2013) y depósitos cuaternarios.

\subsection{Descripción macroscópica y microscópica}

La unidad está compuesta por riolitas y traquitas de grano fino y porfídicas de tonalidades rosa y naranja (figura 2A), con variaciones graduales entre una y otra, que desarrollan saprolitos de colores rosa muy claro a naranja, arcillosos (figura $2 \mathrm{~B}, \mathrm{C}$ ). Las riolitas y traquitas están intruidas localmente por diques centimétricos de andesita (figura 2 D, E) e intruyen los esquistos de la Formación Silgará. Las relaciones de la unidad con el Batolito de Mogotes son complejas. En algunos lugares, las riolitas y traquitas parecen ser intrusivas en rocas del batolito (figura $2 \mathrm{~F}$ ), y en otras parece que los monzogranitos del Batolito de Mogotes las intruyen, aunque los datos geocronológicos sugieren que las riolitas son más antiguas que la facies principal del Batolito de Mogotes. 
A nivel microscópico se identificaron riolitas, riolitas de feldespato alcalino, traquitas de feldespato alcalino (IGM900876, 90091 6, 10914) y diques de andesita porfídica (900877). El resumen de la composición modal se presenta en la tabla 1. Las abreviaturas de los minerales fueron tomadas de Siivola y Schmid (2007). La composición modal se obtuvo por conteo de 300 puntos en cada muestra y se presenta una muestra en el triángulo QAP de Streckeisen (1978) en la figura 3. La clasificación se realizó a partir del contenido de fenocristales.
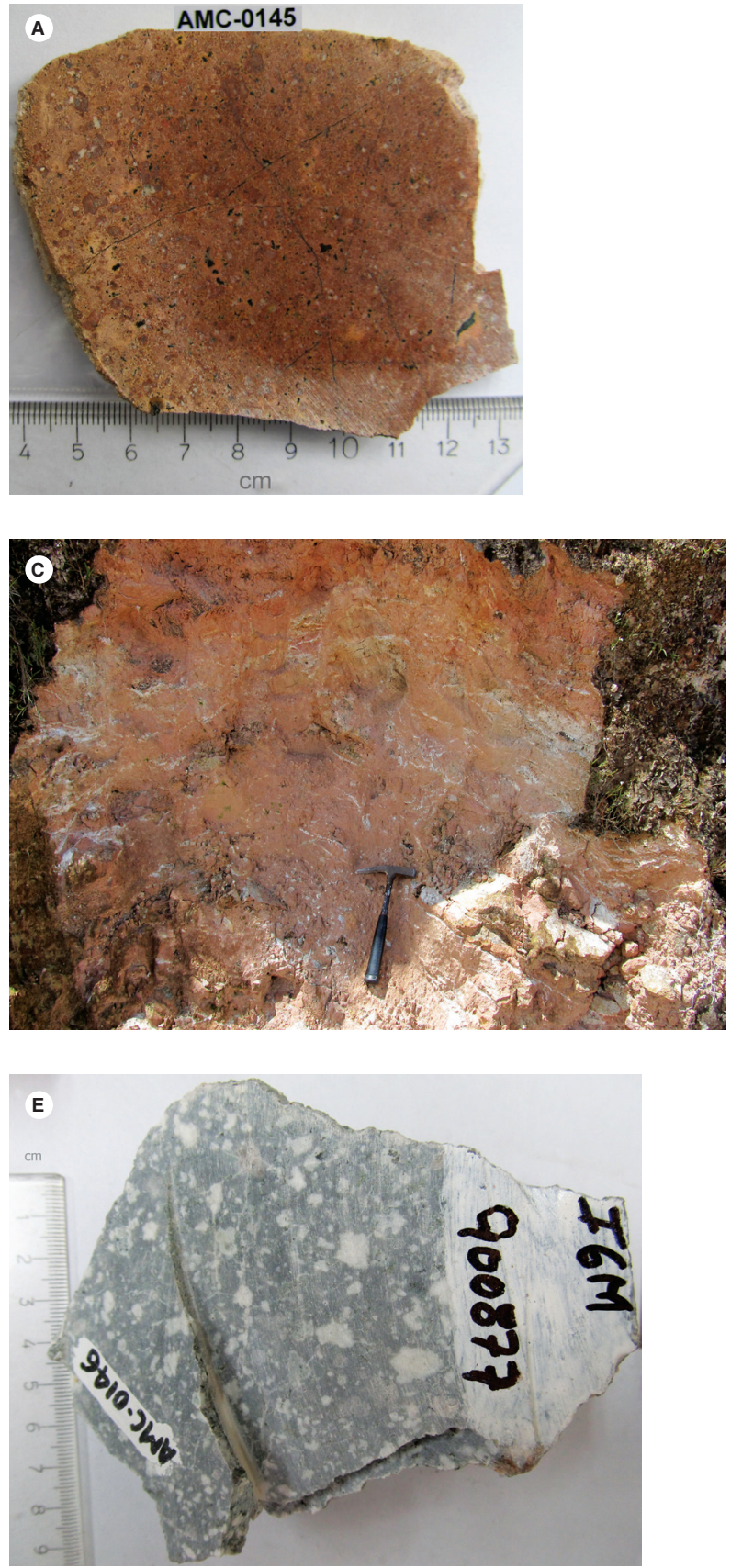
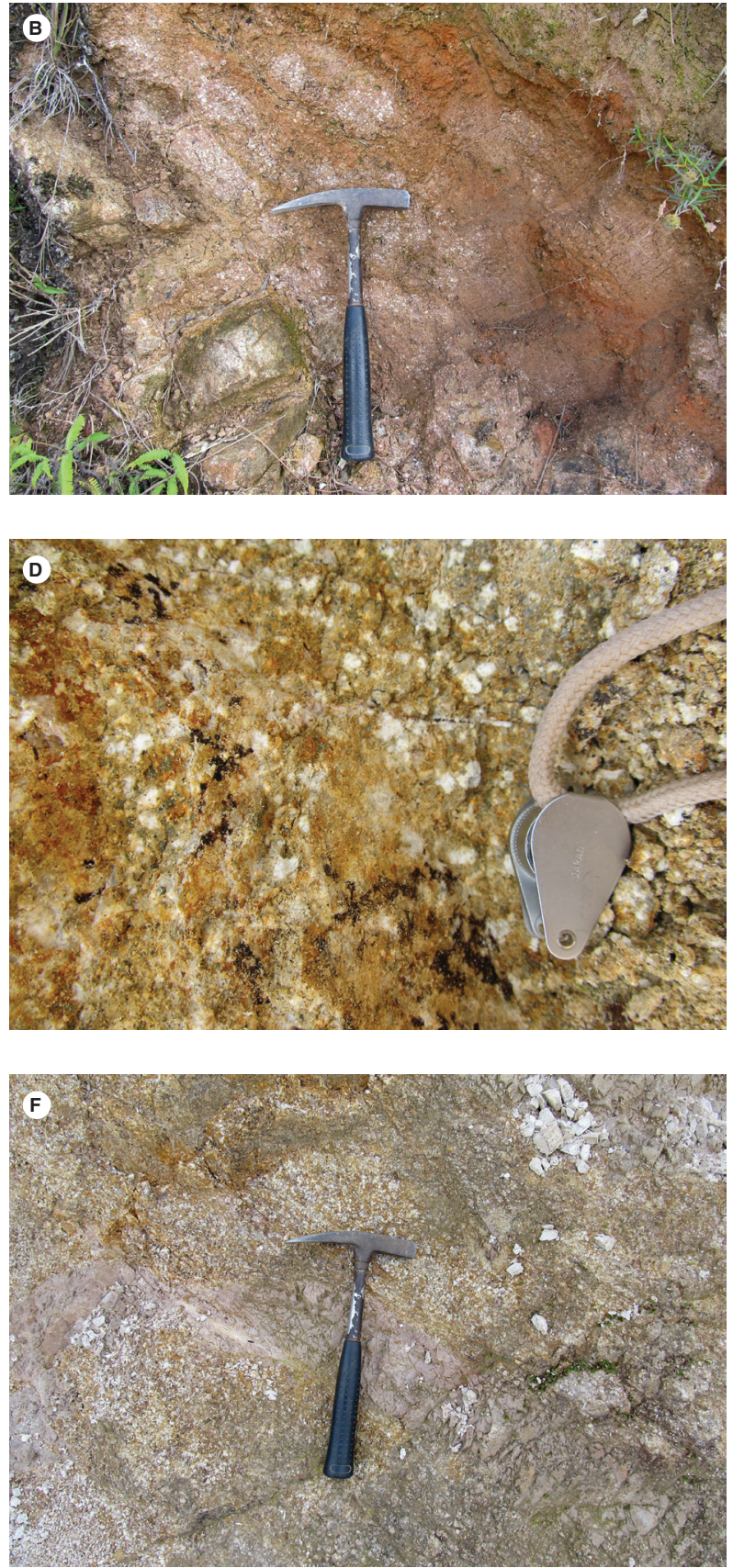

Figura 2. Características macroscópicas de las riolitas, traquitas y de un dique de la unidad Riolitas del Alto Los Cacaos. A) Muestra de mano de traquita de feldespato alcalino levemente microporfídica, colectada en estación AMC-0145 (IGM900976). B) Afloramiento de riolita porfídica saprolitizada. C) Afloramiento de riolita afanítica saprolitizada, con vetillas blancas. D) Imagen mesoscópica del dique de andesita porfídica meteorizado, estación AMC-0146. E) Muestra de mano de dique de andesita colectado en la estación AMC-0146 (IGM900877). F) Cuerpos tabulares de riolita afanítica (en lila) aparentemente cortando un monzogranito 
Tabla 1. Composición modal de las rocas subvolcánicas del cuerpo Riolitas del Alto Los Cacaos

\begin{tabular}{|c|c|c|c|c|c|c|c|c|c|c|c|c|c|c|}
\hline IGM ( $n .^{\circ}$ de campo) & $\begin{array}{c}\text { Coordenada } \\
\text { oeste }\end{array}$ & $\begin{array}{c}\text { Coordenada } \\
\text { norte }\end{array}$ & Qtz & PI & Kfs & Bt & Ms & Op & Ap & Zrn & Ttn & Matriz & Otros & Clasificación \\
\hline 900876 (AMC-0145) & 1132810 & 1203442 & 13 & 4 & 63 & $\operatorname{Tr}$ & & $\operatorname{Tr}$ & & & & 20 & & Cuarzotraquita de feldespato alcalino \\
\hline 10914 (HC-26) & 1133807 & 1203953 & 21 & 20 & 35 & 1 & $\operatorname{Tr}$ & 2 & & $\operatorname{Tr}$ & & 21 & & Riolita \\
\hline 900916 (JGB-469) & 1133266 & 1203094 & 12,7 & & 17,3 & 0,7 & & $\operatorname{Tr}$ & & & & 69,3 & & Riolita de feldespato alcalino \\
\hline $900877^{\star}($ AMC-0146) & 1132182 & 1204891 & 2 & 15,5 & 2 & & & 0,5 & $\operatorname{Tr}$ & $\operatorname{Tr}$ & $\operatorname{Tr}$ & 70 & 10 & Andesita porfídica \\
\hline
\end{tabular}

`Muestra de dique. Qtz: cuarzo; PI: plagioclasa; Kfs: feldespato potásico, Bt: biotita, Ms: moscovita; Op: opacos; Ap: apatito; Zrn: circón; Tnt: titanita

1 Traquita de fedespato alcalino

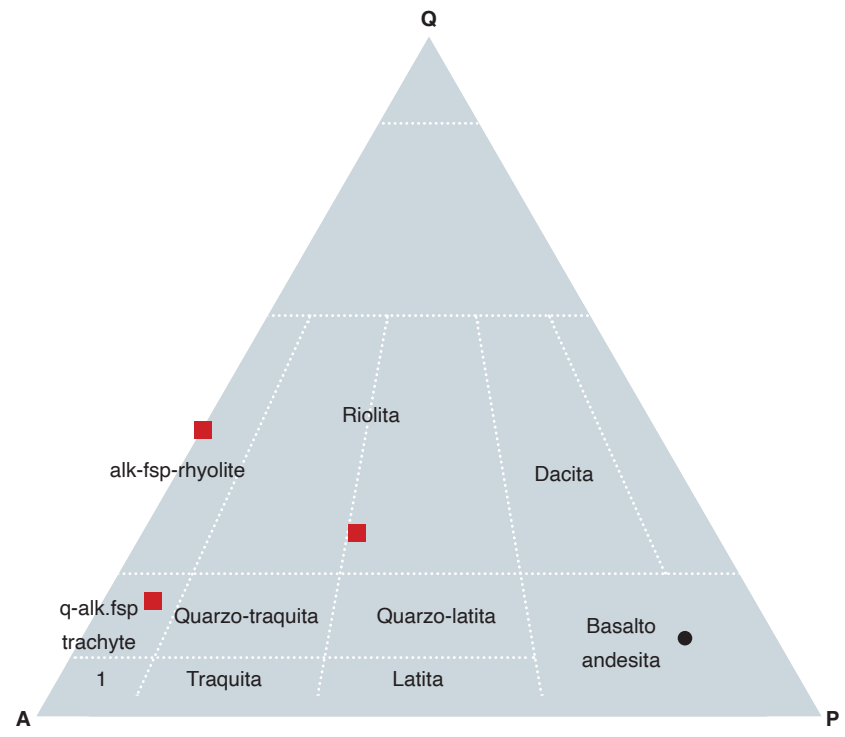

Figura 3. Triángulo de Streckeisen (1978) en el que se muestra la composición modal de las rocas subvolcánicas de la unidad Riolitas del Alto Los Cacaos. En rojo, riolitas y traquitas; en negro, dique que corta las anteriores

\subsubsection{Riolitas y traquitas}

Las riolitas y traquitas exhiben texturas esferulítica, porfídica y micrográfica con matriz felsítica (figura $4 \mathrm{~A}$, B, C, D, E). Estas rocas tienen aproximadamente 70\% de fenocristales y $20 \%$ de matriz, y están compuestas por feldespato potásico (60\% a $65 \%$ ), cuarzo (10\% a $15 \%$ ), plagioclasa (5\%), y como accesorios, opacos y trazas de un mineral ferromagnesiano alterado que posiblemente era biotita.

El feldespato potásico se presenta de dos maneras: una es en cristales esferulíticos intercrecidos con cuarzo (figura 4 A, B, C), y la otra en cristales subhedrales tabulares con textura gráfica (figura 4 D, E). En ambos casos exhibe la superficie sucia con un polvillo de color pardo por alteración a caolín de moderada a fuerte. Algunos de los cristales subhedrales exhiben macla de Carlsbad, y otros, crecimientos micrográficos. En las esferulitas se distinguen dos poblaciones: una de $0,3 \mathrm{~mm}$ de diámetro, aproximadamente, y la otra de $0,7 \mathrm{~mm}$ de diámetro en promedio. Entre los cristales subhedrales predominan los que tienen dimensiones de 0,7 x 1,2 mm. Esporádicamente pueden encontrarse de mayor tamaño.

El cuarzo está en microfenocristales y microcristales, principalmente bipiramidales $y$, en menor proporción, anhedrales (figura 4 A, C), rodeados por esferulitas y, localmente, por cristales de feldespato potásico. Algunos exhiben rasgos de corrosión en su interior y en pequeñas bahías en sus bordes. El cuarzo forma parte también de los intercrecimientos esferulíticos y micrográficos (figura 4 A, B, D, E). Los cristales de cuarzo presentan extinción levemente ondulante y predominan los menores de 0,5 mm; excepcionalmente alcanzan $1 \mathrm{~mm}$ en su dimensión mayor.

La plagioclasa se encuentra en cristales anhedrales y subhedrales tabulares, con macla de albita, con sericitización moderada y argilización muy fuerte, por lo que no es posible estimar su composición a partir del método Michel-Lévy. El tamaño predominante es de 0,4 x 0,5 mm.

Unas láminas anhedrales completamente alteradas a clorita y a opacos, que posiblemente correspondían a 
biotita, se encuentran en muy poca cantidad, con tamaños menores de $0,3 \times 0,75 \mathrm{~mm}$.

Hay varios tipos de opacos. Unos, que parecen ser primarios, tienden a ser equidimensionales o rectangulares, con un tamaño menor o igual a $0,25 \mathrm{~mm}$ en su dimensión mayor. Y entre estos se reconocen dos clases: la primera, representada por los que están relativamen-
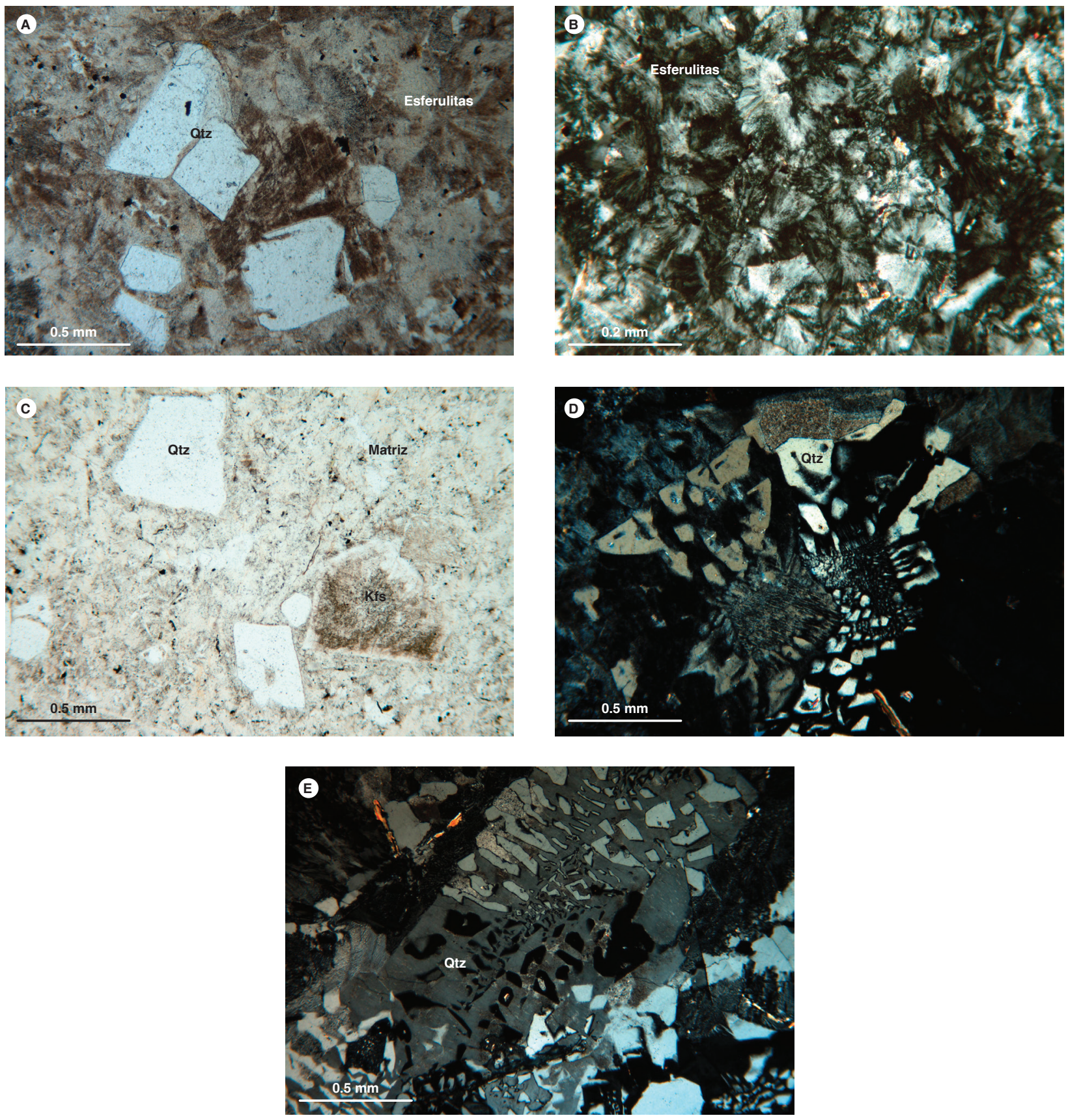

Figura 4. Texturas y composición de las Riolitas del Alto Los Cacaos. A) IGM900876. Microfenocristales de cuarzo y matriz esferulítica. B) IGM900916. Detalle de la matriz esferulítica. C) IGM900916 Microfenocristales de cuarzo y feldespato potásico en matriz felsítica y esferulítica. D) IGM900876. Fenocristal de feldespato potásico con textura gráfica. E) IGM10914. Textura micrográfica

te bien preservados, de superficie más homogénea, color crema y reflectancia mayor que la que se observa en los de la segunda, que son de tonalidad gris y están poco preservados. Otros son anhedrales y de grano más fino, que son de alteración; se hallan diseminados en la roca y localmente asociados a minerales de alteración, y pueden corresponder a magnetita. 


\subsubsection{Dique andesítico}

El dique de andesita exhibe textura porfídica (figura 5) con matriz felsítica micrográfica y desvitrificada (figura 5 ), con $30 \%$ de cristales y $70 \%$ de matriz. Son comunes los glomerocristales de plagioclasa \pm cuarzo \pm feldespato potásico. Los cristales están representados por plagioclasa (16\%), ferromagnesiano alterado (10\%), cuarzo (2\%), feldespato potásico (2\%), accesorios opacos, apatito, circón y titanita.

La plagioclasa se presenta en fenocristales y microfenocristales euhedrales y subhedrales (figura 5), con maclas de albita y combinada de albita-Carlsbad. Está principalmente en glomerocristales, y en menor proporción se presentan aislada. Hay cristales incoloros y otros de centros con superficie parduzca por sericitización muy fuerte y bordes limpios no alterados. Además, pueden exhibir algo de argilización y saussuritización. Algunos presentan zonación. Los tamaños varían desde 0,3 x $0,75 \mathrm{~mm}$ hasta $1,7 \times 2,5 \mathrm{~mm}$.

El mineral ferromagnesiano alterado, por las formas que preserva, parece haber correspondido en su mayoría a biotita y, en menor cantidad, a anfíbol. Las láminas subhedrales de una posible biotita, con un tamaño de 0,250,5 x 1,1-1,75 mm, están completamente alteradas a clorita y epidota. Por otro lado, un fenocristal que parece haber sido anfíbol, por su contorno, está alterado a clorita, epidota y opacos; su tamaño es de 0,75 x 1,1 mm.

El cuarzo aparece en fenocristales y microfenocristales subhedrales bipiramidales, incoloros y limpios. Estos cristales pueden exhibir bahías de corrosión y estar rodeados por matriz con textura micrográfica y esferulí-

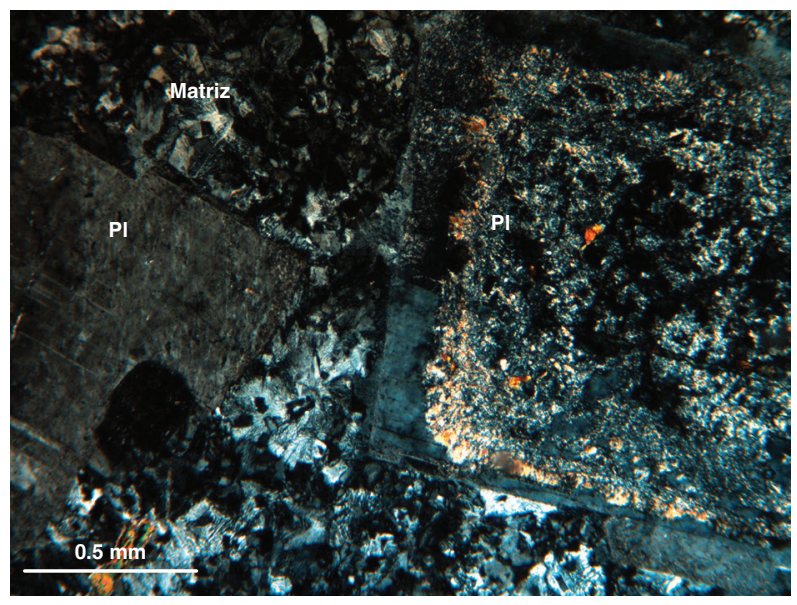

Figura 5. Características microscópicas de dique de andesita. IGM900877. Fenocristales de plagioclasa y matriz felsítica tica. Los tamaños del cuarzo en la muestra del dique analizado van desde 0,3 x 0,4 mm hasta 2,25 x 3,0 mm, pero el promedio es de 1,2 x 1,5 mm.

El feldespato potásico se presenta en fenocristales y microfenocristales subhedrales con argilización moderada, por lo que muestran superficie levemente empolvada. Algunos tienen macla de Carlsbad y exhiben zonación. Los tamaños de los cristales van desde 0,3 x 0,7 mm hasta $1,0 \times 1,25 \mathrm{~mm}$.

Los opacos aparecen de dos formas: unos son subhedrales de contornos cuadrados, que posiblemente corresponden a minerales primarios; algunos de ellos tienen apatito en sus bordes. El otro tipo de opaco es anhedral y aparece en agregados menores de 0,25 mm de diámetro; se encuentra principalmente dentro del mineral ferromagnesiano alterado, y posiblemente es secundario.

El apatito se presenta en cristales euhedrales prismáticos y subhedrales asociados a un mineral ferromagnesiano alterado y a opacos primarios. Los hallados son menores de 0,06 x 0,1 mm.

La titanita se encuentra en cristales subhedrales diseminados en la roca, que puede ser primaria. También hay titanita que parece ser de alteración, asociada al mineral ferromagnesiano alterado.

El circón está en cristales euhedrales prismáticos finos diseminados en la roca. Su tamaño promedio es de $0,02 \times 0,04 \mathrm{~mm}$.

\section{Química mineral}

Los análisis de química mineral se llevaron a cabo en la microsonda electrónica de la Universidad Nacional de Colombia, sede Bogotá. El equipo usado es una microsonda JEOL JXA 8230. Estas fueron las condiciones de operación: 1 a $10 \mu \mathrm{m}$ de diámetro del haz, tiempo en el pico de $20 \mathrm{~ms}$, intensidad de $20 \mathrm{nA}$ y voltaje de aceleración de $15 \mathrm{kV}$. Los conteos del instrumento son convertidos a porcentajes de óxidos mediante comparaciones con conteos de estándares naturales y sintéticos. Los datos se han tratado mediante la corrección ZAF (Z: número atómico; A: absorción de masas; F: fluorescencia), utilizando el programa de JEOL. La adquisición de los datos consistió en obtener imágenes de electrones retrodispersados de los cristales seleccionados para el análisis y en realizar los análisis puntuales.

En la muestra IGM900876 de las Riolitas del Alto Los Cacaos, los minerales analizados fueron feldespato potásico, plagioclasa y magnetita. 


\subsection{Feldespato potásico}

Los cristales de feldespato potásico de esta muestra se encuentran fuertemente caolinizados, y por tal motivo se analizaron en los bordes, donde no se apreciaba caolinización. Las imágenes de electrones retrodispersados de los cristales analizados se exhiben en la figura 6. Los resultados están en la tabla 2.

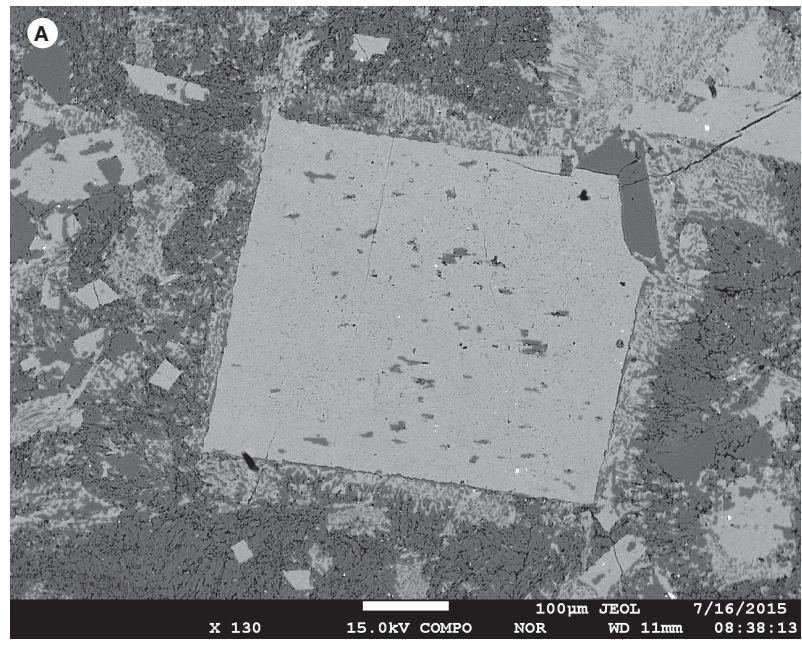

El feldespato de la muestra AMC-0145 exhibe una composición relativamente homogénea de ortosa $\left(\mathrm{Or}_{96,5-}\right.$ ${ }_{97,5} \mathrm{Ab}_{2,5-3,5}$ ), exceptuando dos resultados con contenido de ortosa un poco más bajos: $\mathrm{Or}_{94} \mathrm{Ab}_{6}$ y $\mathrm{Or}_{89} \mathrm{Ab}_{11}$ (figura 7).

Figura 6. Imágenes de electrones retrodispersados de los feldespatos potásicos analizados en la muestra AMC-0145

Tabla 2. Composición química del feldespato potásico en la muestra IGM900876 (AMC-0145) de las Riolitas del Alto Los Cacaos

\begin{tabular}{|c|c|c|c|c|c|c|c|c|c|}
\hline Punto analizado & $\begin{array}{c}\text { AMC-0145-C3- } \\
\text { Kfs-1 }\end{array}$ & $\begin{array}{c}\text { AMC-0145-C3- } \\
\text { Kfs-2 }\end{array}$ & $\begin{array}{c}\text { AMC-0145-C3- } \\
\text { Kfs-3 }\end{array}$ & $\begin{array}{c}\text { AMC-0145-C3- } \\
\text { Kfs-4 }\end{array}$ & $\begin{array}{c}\text { AMC-0145-C4- } \\
\text { Kfs-1 }\end{array}$ & $\begin{array}{c}\text { AMC-0145-C4- } \\
\text { Kfs-2 }\end{array}$ & $\begin{array}{c}\text { AMC-0145-C4- } \\
\text { Kfs-3 }\end{array}$ & $\begin{array}{c}\text { AMC-0145-C4- } \\
\text { Kfs-4 }\end{array}$ & $\begin{array}{c}\text { AMC-0145-C4- } \\
\text { Kfs-5 }\end{array}$ \\
\hline $\mathrm{SiO}_{2}$ & 66,13 & 65,28 & 66,05 & 66,03 & 65,48 & 65,21 & 65,37 & 65,40 & 65,05 \\
\hline $\mathrm{TiO}_{2}$ & 0,00 & 0,00 & 0,00 & 0,01 & 0,01 & 0,00 & 0,00 & 0,00 & 0,00 \\
\hline $\mathrm{Al}_{2} \mathrm{O}_{3}$ & 17,52 & 17,46 & 17,27 & 17,26 & 17,55 & 17,37 & 17,53 & 17,19 & 17,57 \\
\hline $\mathrm{FeO}$ & 0,09 & 0,03 & 0,04 & 0,09 & 0,00 & 0,04 & 0,02 & 0,02 & 0,02 \\
\hline $\mathrm{MgO}$ & 0,00 & 0,00 & 0,00 & 0,00 & 0,00 & 0,00 & 0,00 & 0,00 & 0,00 \\
\hline $\mathrm{CaO}$ & 0,00 & 0,00 & 0,00 & 0,03 & 0,00 & 0,01 & 0,02 & 0,02 & 0,00 \\
\hline $\mathrm{Na}_{2} \mathrm{O}$ & 0,32 & 0,32 & 0,28 & 1,16 & 0,39 & 0,31 & 0,66 & 0,28 & 0,32 \\
\hline $\mathrm{K}_{2} \mathrm{O}$ & 15,41 & 16,04 & 16,12 & 14,35 & 15,94 & 16,11 & 15,76 & 16,17 & 16,19 \\
\hline Total (\% en peso) & 99,46 & 99,13 & 99,76 & 98,92 & 99,38 & 99,05 & 99,35 & 99,09 & 99,14 \\
\hline $\mathrm{Si}$ & 12,201 & 12,145 & 12,203 & 12,215 & 12,144 & 12,150 & 12,131 & 12,180 & 12,115 \\
\hline $\mathrm{Al}$ & 3,810 & 3,829 & 3,759 & 3,763 & 3,835 & 3,814 & 3,833 & 3,774 & 3,857 \\
\hline $\mathrm{Fe}$ & 0,000 & 0,000 & 0,000 & 0,002 & 0,002 & 0,000 & 0,000 & 0,000 & 0,000 \\
\hline $\mathrm{Ti}$ & 0,009 & 0,003 & 0,004 & 0,009 & 0,000 & 0,004 & 0,002 & 0,002 & 0,002 \\
\hline $\mathrm{Mg}$ & 0 & 0 & 0 & 0 & 0 & 0 & 0 & 0 & 0 \\
\hline $\mathrm{Na}$ & 0,114 & 0,117 & 0,101 & 0,415 & 0,140 & 0,111 & 0,237 & 0,100 & 0,115 \\
\hline $\mathrm{Ca}$ & 0,000 & 0,000 & 0,000 & 0,005 & 0,000 & 0,003 & 0,003 & 0,004 & 0,000 \\
\hline $\mathrm{K}$ & 3,627 & 3,806 & 3,800 & 3,387 & 3,772 & 3,829 & 3,731 & 3,842 & 3,847 \\
\hline $\begin{array}{c}\text { Total cationes } \\
\text { (a.p.f.u.) }\end{array}$ & 19,761 & 19,900 & 19,866 & 19,797 & 19,893 & 19,911 & 19,936 & 19,903 & 19,936 \\
\hline 0 & 32 & 32 & 32 & 32 & 32 & 32 & 32 & 32 & 32 \\
\hline$z$ & 16,01 & 15,97 & 15,96 & 15,98 & 15,98 & 15,96 & 15,96 & 15,95 & 15,97 \\
\hline$x$ & 3,75 & 3,93 & 3,90 & 3,82 & 3,91 & 3,95 & 3,97 & 3,95 & 3,96 \\
\hline Or & 96,94 & 97,02 & 97,41 & 88,96 & 96,43 & 97,13 & 93,95 & 97,36 & 97,08 \\
\hline$A b$ & 3,06 & 2,98 & 2,59 & 10,90 & 3,57 & 2,80 & 5,97 & 2,54 & 2,91 \\
\hline An & 0,01 & 0,00 & 0,00 & 0,14 & 0,01 & 0,07 & 0,09 & 0,10 & 0,01 \\
\hline
\end{tabular}

a.p.f.u.: átomos por fórmula unitaria 


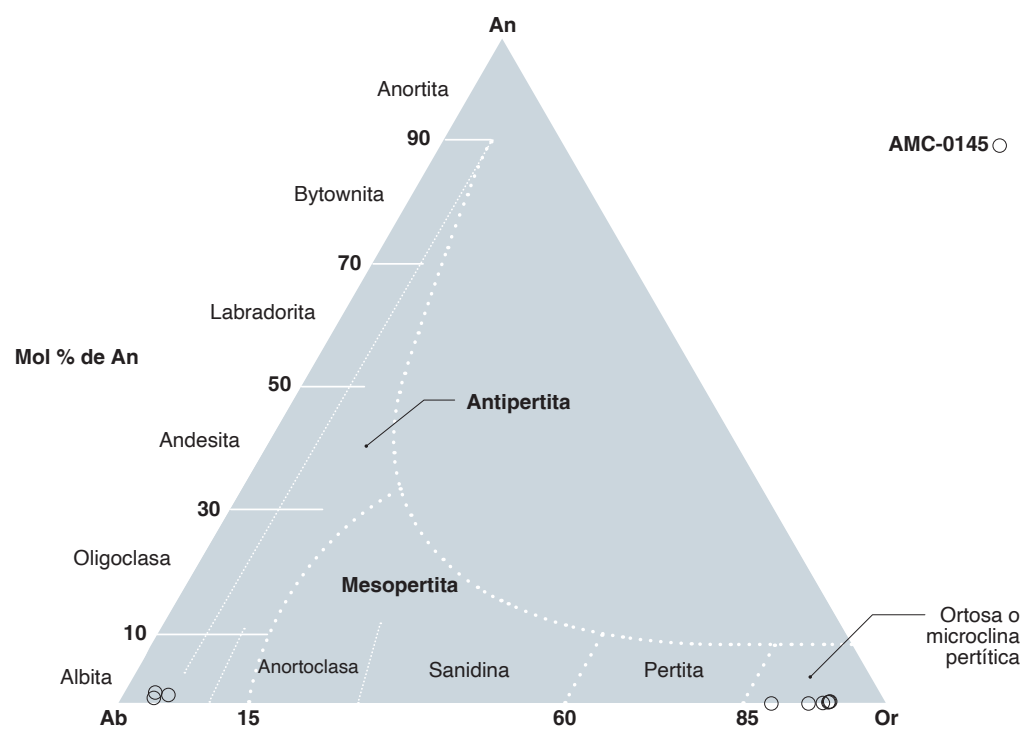

Figura 7. Composición de los feldespatos potásicos y las plagioclasas en una muestra de las Riolitas del Alto Los Cacaos. Diagrama de Smith y Brown (1988)

\subsection{Plagioclasa}

Las plagioclasas también se encuentran fuertemente alteradas a sericita, arcilla y, en menor proporción, a saussurita, por lo que se analizaron en los bordes, donde la superficie se apreciaba aparentemente limpia. En las imágenes de electrones retrodispersados (figura 8) no se observó zonación. La composición obtenida en tres puntos es muy homogénea y corresponde a albita $\left(\mathrm{Ab}_{95,5-97,5} \mathrm{An}_{1-1,6} \mathrm{Or}_{1,5-3,3}\right)$, como se puede observar en la tabla 3 y en la figura 7.

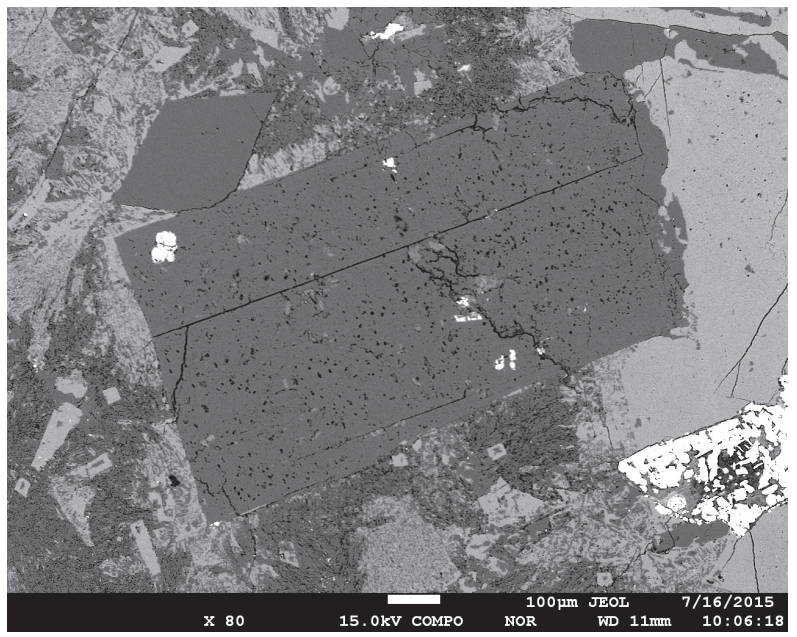

Figura 8. Cristal de plagioclasa de la muestra AMC-0145 analizado en la microsonda electrónica. Imagen de electrones retrodispersados
Tabla 3. Composición química de la plagioclasa en la muestra IGM900876 (AMC-0145) de las Riolitas del Alto Los Cacaos

\begin{tabular}{|c|c|c|c|}
\hline $\begin{array}{c}\text { Punto } \\
\text { analizado }\end{array}$ & AMC-0145-C6-PI-1 & AMC-0145-C6-PI-2 & AMC-0145-C6-PI-4 \\
\hline $\mathrm{SiO}_{2}$ & 66,90 & 67,83 & 67,78 \\
\hline $\mathrm{TiO}_{2}$ & 0,00 & 0,00 & 0,00 \\
\hline $\mathrm{Al}_{2} \mathrm{O}_{3}$ & 20,57 & 20,31 & 20,58 \\
\hline $\mathrm{FeO}$ & 0,05 & 0,03 & 0,00 \\
\hline $\mathrm{MgO}$ & 0,00 & 0,00 & 0,00 \\
\hline $\mathrm{CaO}$ & 0,27 & 0,35 & 0,22 \\
\hline $\mathrm{Na}_{2} \mathrm{O}$ & 11,52 & 11,84 & 11,75 \\
\hline $\mathrm{K}_{2} \mathrm{O}$ & 0,61 & 0,24 & 0,27 \\
\hline $\begin{array}{c}\text { Total } \\
\text { (\% en peso) }\end{array}$ & 99,93 & 100,60 & 100,60 \\
\hline $\mathrm{Si}$ & 11,759 & 11,822 & 11,805 \\
\hline $\mathrm{Al}$ & 4,260 & 4,172 & 4,224 \\
\hline $\mathrm{Fe}$ & 0,000 & 0,000 & 0,000 \\
\hline $\mathrm{Ti}$ & 0,005 & 0,003 & 0,000 \\
\hline $\mathrm{Mg}$ & 0,000 & 0,000 & 0,000 \\
\hline $\mathrm{Na}$ & 3,927 & 4,001 & 3,966 \\
\hline $\mathrm{Ca}$ & 0,052 & 0,065 & 0,042 \\
\hline K & 0,137 & 0,054 & 0,059 \\
\hline $\begin{array}{c}\text { Total cationes } \\
\text { (a.p.f.u.) }\end{array}$ & 20,140 & 20,118 & 20,096 \\
\hline 0 & 32 & 32 & 32 \\
\hline z & 16,02 & 16,00 & 16,03 \\
\hline$x$ & 4,12 & 4,12 & 4,07 \\
\hline$A b$ & 95,42 & 97,10 & 97,52 \\
\hline An & 1,25 & 1,59 & 1,02 \\
\hline Or & 3,32 & 1,31 & 1,46 \\
\hline
\end{tabular}

a.p.f.u.: átomos por fórmula unitaria 


\subsection{Magnetita}

Se analizó un cristal de magnetita en la muestra AMC0145 (figura 9); los resultados obtenidos se presentan en la tabla 4. El cálculo del $\mathrm{Fe}^{3+}$ se hizo usando la fórmula de Droop (1987).

La magnetita de esta muestra tiene un contenido de $\mathrm{FeO}_{\text {total }}$ entre $88,3 \%$ y $89,6 \%$ (10,8 a.p.f.u. de $\mathrm{Fe}^{3+}$ y aproximadamente 12 a.p.f.u. de $\mathrm{Fe}^{2+}$ ) y es rica en $\mathrm{TiO}_{2}$ porque presenta valores entre 4,6\% y 4,9\% (1,06 a 1,13 a.p.f.u.). Exhibe bajos contenidos de Al, Cr y Mn.

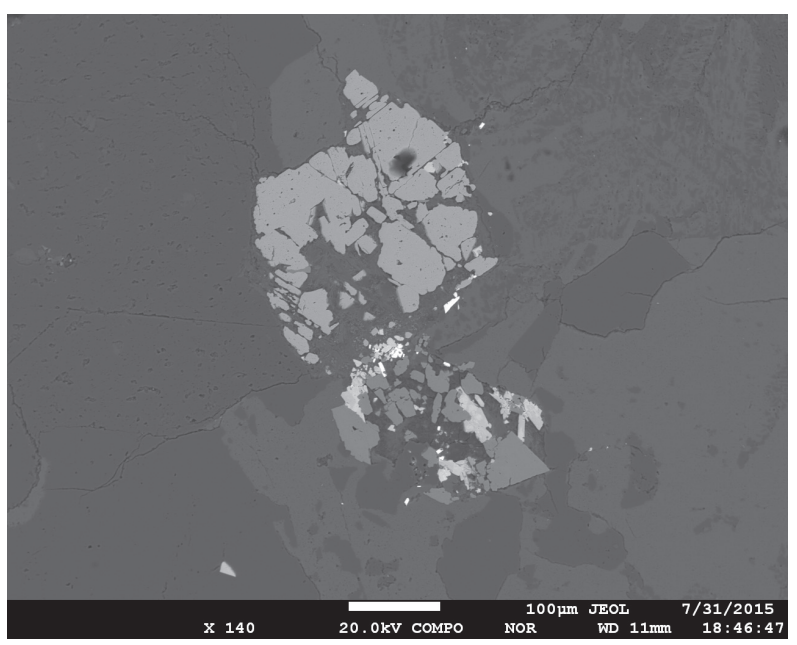

Figura 9. Cristal de magnetita analizado en la muestra AMC-0145

Tabla 4. Composición química de la magnetita en la muestra AMC-0145

\begin{tabular}{|c|c|c|c|}
\hline $\begin{array}{c}\text { Punto } \\
\text { analizado }\end{array}$ & AMC-0145-C2-Mt-1 & AMC-0145-C2-Mt-2 & AMC-0145-C2-Mt-3 \\
\hline $\mathrm{SiO}_{2}$ & ND & ND & ND \\
\hline $\mathrm{TiO}_{2}$ & 4,731 & 4,617 & 4,886 \\
\hline $\mathrm{Al}_{2} \mathrm{O}_{3}$ & 0,075 & 0,029 & 0,06 \\
\hline $\mathrm{Cr}_{2} \mathrm{O}_{3}$ & ND & 0,008 & ND \\
\hline $\mathrm{FeO}$ & 89,619 & 89,389 & 88,268 \\
\hline $\mathrm{MnO}$ & 0,336 & 0,041 & 0,372 \\
\hline $\mathrm{MgO}$ & 0,002 & ND & ND \\
\hline $\begin{array}{c}\text { Total (\% en } \\
\text { peso) }\end{array}$ & 94,763 & 94,084 & 93,586 \\
\hline $\mathrm{Si}$ & ND & ND & ND \\
\hline $\mathrm{Ti}$ & 1,083 & 1,064 & 1,133 \\
\hline $\mathrm{Al}$ & 0,027 & 0,010 & 0,022 \\
\hline $\mathrm{Cr}$ & ND & 0,002 & ND \\
\hline $\mathrm{Fe}^{3+}$ & 10,829 & 10,858 & 10,775 \\
\hline $\mathrm{Fe}^{2+}$ & 11,974 & 12,055 & 11,974 \\
\hline $\mathrm{Mg}$ & 0,001 & ND & ND \\
\hline $\mathrm{Mn}$ & 0,087 & 0,011 & 0,097 \\
\hline $\begin{array}{l}\text { Total cationes } \\
\text { (a.p.f.u.) }\end{array}$ & 24,000 & 24,000 & 24,000 \\
\hline
\end{tabular}

ND: no detectado

\section{Geoquímica}

Los análisis geoquímicos se hicieron en el laboratorio del Servicio Geológico Colombiano, en Bogotá. La cuantificación de los óxidos mayores se realizó con un espectrómetro de fluorescencia de rayos X, Panalytical AXIOS Mineral, para análisis elemental, configurado con software especializado para materiales geológicos, en muestra fundida con metaborato y tetraborato de litio, y la de elementos menores se hizo en muestra prensada. Para el análisis de elementos traza se usó un espectrómetro de masas con plasma inductivamente acoplado, ICP-MS, Perkin Elmer Nexion. La disolución de la muestra se ejecutó mediante ataque por pasos utilizando ácidos inorgánicos fuertes ( $\left.\mathrm{HF}, \mathrm{HNO}_{3}, \mathrm{HClO}_{4} \mathrm{y} \mathrm{HCl}\right)$. El proceso se realizó en sistema abierto, empleando distintas rampas de temperatura y tiempos de calentamiento.

Los valores de óxidos mayores se presentan en porcentaje en peso (\% en peso), mientras que los elementos traza se presentan en partes por millón (ppm). Gran parte de los diagramas geoquímicos se generaron con el uso del GCDKit versión 4.0 (Janoušek et al., 2006).

\subsection{Elementos mayores}

Los resultados analíticos de los elementos mayores se presentan en la tabla 5. La pérdida al fuego (LOI) en las tres muestras es menor del $2 \%$, y este criterio indicaría que las rocas que no están muy alteradas, así como los análisis de elementos mayores, se podrían usar para clasificaciones e interpretaciones geoquímicas petrogenéticas. Sin embargo, dadas las evidencias macroscópicas y microscópicas de alteración de las muestras, se analizan las posibilidades de alteración por meteorización o por alteración hidrotermal. En el diagrama de Nesbitt y Young (1984), que se usa para mostrar tendencias de meteorización de las rocas, se observa que las dos muestras de riolitas están relativamente alteradas por meteorización (figura 10A), mientras que el dique está menos meteorizado. En este diagrama también se aprecia que una de las muestras de riolita (IGM900916_JGB-469) posiblemente sufrió metasomatismo potásico, ya que se ubica por debajo de la línea de tendencia de meteorización de riolitas y más hacia el vértice de $\mathrm{K}_{2} \mathrm{O}$. Según lo observado en el diagrama de Hughes (1972), que muestra los campos de rocas con composiciones ígneas o alteraciones potásica y sódica, las muestras de riolitas presentan alteración potásica (figura 10B), mientras que el dique está en el campo de las composiciones ígneas, pero cerca del límite de la alteración potásica. 
Tabla 5. Resultados de óxidos mayores (expresado en porcentaje en peso) de rocas de las Riolitas del Alto Los Cacaos y de un dique en estas

\begin{tabular}{ccccccccccc}
\hline IGM & $\mathrm{SiO}_{2}$ & $\mathrm{TiO}_{2}$ & $\mathrm{Al}_{2} \mathrm{O}_{3}$ & $\mathrm{Fe}_{2} \mathrm{O}_{3}$ & $\mathrm{MgO}$ & $\mathrm{CaO}$ & $\mathrm{Na}_{2} \mathrm{O}$ & $\mathrm{K}_{2} \mathrm{O}$ & $\mathrm{MnO}$ & LOI \\
\hline 900876 & 73,65 & 0,15 & 15,98 & 1,08 & 0,07 & 0,20 & 2,28 & 4,63 & 0,02 & 0,98 \\
\hline 900916 & 76,89 & 0,02 & 11,97 & 1,01 & 0,02 & 0,14 & 1,78 & 5,72 & 0,01 & 1,62 \\
\hline $900877^{*}$ & 66,58 & 0,47 & 18,01 & 2,86 & 0,58 & 2,28 & 2,94 & 4,50 & 0,08 & 0,72
\end{tabular}

* Dique

A

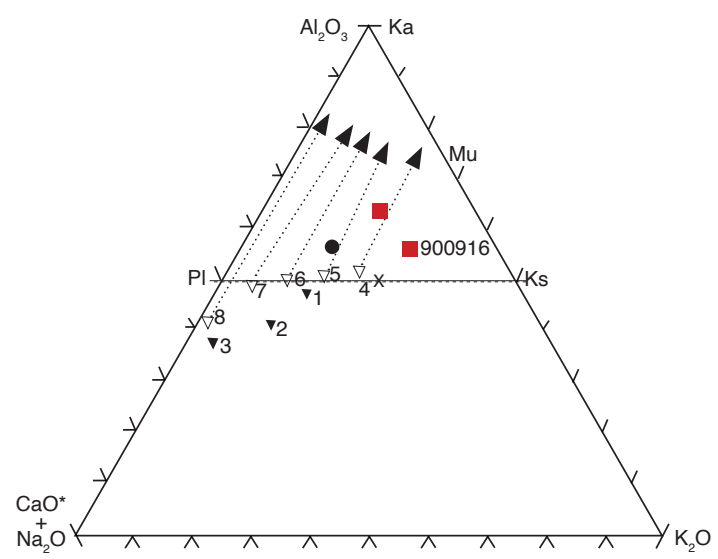

B

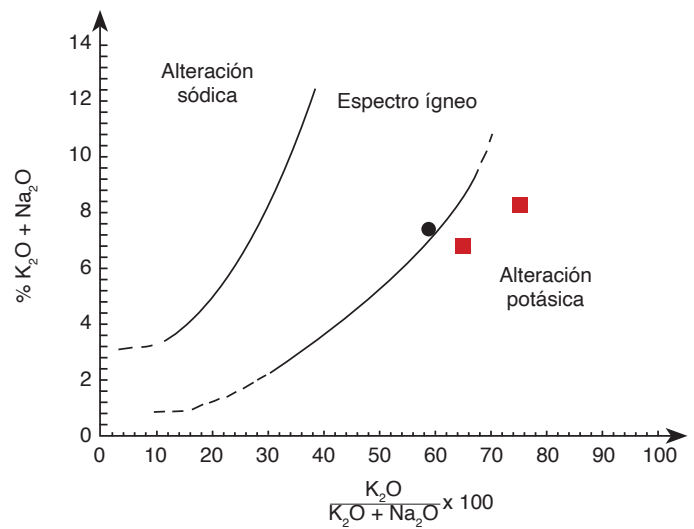

Figura 10. A) Muestras de riolitas (cuadros rojos) y dique (círculo negro) en el diagrama de Nesbitt y Young (1984), donde se muestran composiciones de rocas frescas y tendencias de meteorización. B) Diagrama de Hughes (1972) para mostrar alteración hidrotermal de rocas volcánicas En la figura 10A. PI: plagioclasa; Ks: feldespato potásico; Mu: moscovita; Ka: caolinita. 1: Composición promedio de riolita, 2: promedio de latita, 3: promedio de basalto, 4: promedio de granito, 5: promedio de adamelita; 6: promedio de granodiorita, 7: promedio de tonalita, 8: promedio de gabro. $\mathrm{El} \mathrm{CaO}{ }^{*}$ corresponde al total del análisis, porque estas muestras no tenían análisis de $\mathrm{P}_{2} \mathrm{O}_{5}$ disponible para calcular qué parte del $\mathrm{CaO}$ correspondía al apatito.

En el diagrama TAS (figura 11A) las rocas subvolcánicas del cuerpo principal y el dique grafican por debajo del límite de Irvine y Baragar (1971), lo que indica que pertenecen a la serie subalcalina. En este mismo diagrama, las rocas subvolcánicas del cuerpo principal se clasifican como riolitas, clasificación que coincide con la petrográfica, mientras que el dique químicamente se clasifica como dacita, y petrográficamente, como andesita. Dada la alteración potásica de dos de las muestras, también se usó para su clasificación el diagrama de Winchester y Floyd (1977) (figura 11B), que se basa en elementos considerados inmóviles, en vez de los álcalis, que son muy móviles. Se aprecia que hay concordancia en la clasificación de las rocas en los dos diagramas (figura 11 A y B).
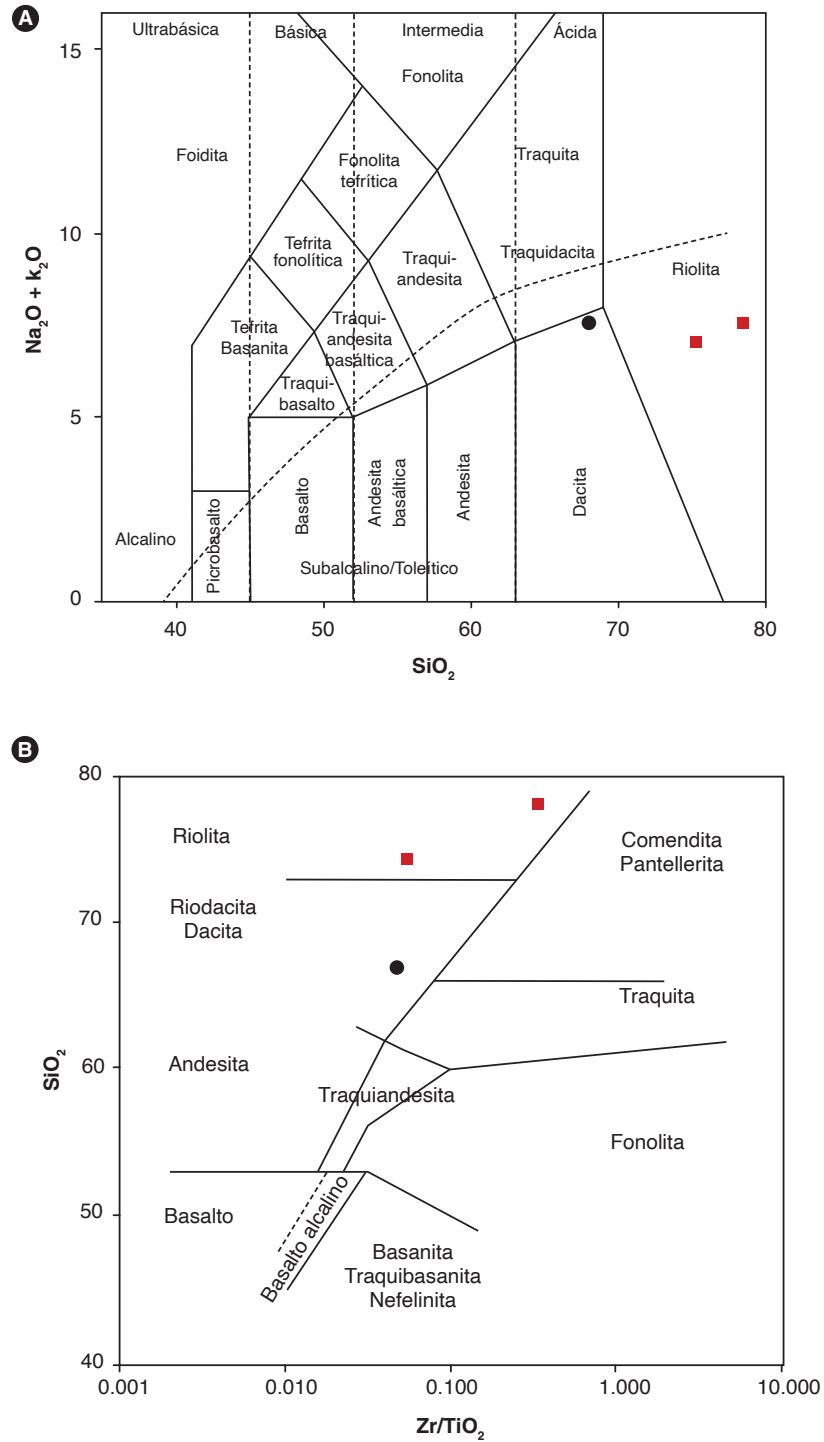

Figura 11. A) Diagrama TAS de Le Bas et al. (1986), con línea punteada de Irvine y Baragar (1971) de las rocas de las Riolitas del Alto Los Cacaos y de un dique en estas. B) Las mismas muestras en el diagrama de Winchester y Floyd (1977). Riolitas en cuadrados rojos, dique en círculo negro 


\subsection{Elementos traza}

Los resultados de elementos traza y de las tierras raras de las rocas de la unidad Riolitas del Alto Los Cacaos se presentan en la tabla 6.

Los patrones de elementos de las tierras raras (REE) normalizados al condrito (McDonough y Sun, 1995) se muestran en la figura 12. Las riolitas tienen contenidos de elementos de las tierras raras $\sum$ REE entre 126 y 145 , con un enriquecimiento en LREE de aproximadamente 100 veces con relación al condrito, mientras que la andesita tiene mayores contenidos de estos con $\sum$ REE de 255, y muestra un enriquecimiento en LREE de 200 veces los valores del condrito. La razón $\mathrm{La} / \mathrm{Yb}_{\mathrm{N}}$ es mayor en la dacita $(22,88)$ que en las riolitas $(4,77-7,71)$, e indica un patrón más empinado (figura 12) y mayor fraccionamiento de las tierras raras livianas con relación a las pesadas en la andesita que en las riolitas. De todos modos, las riolitas también exhiben un patrón con pendiente negativa. En las riolitas, la razón $\mathrm{Gd} / \mathrm{Yb}_{\mathrm{N}}$ próxima de 1 $(0,77$ y 0,98$)$ refleja la tendencia plana del patrón en los HREE. Por otro lado, la anomalía negativa de Eu es más significativa en las riolitas $(0,51$ a 0,56$)$ que en la dacita $(0,86)$, lo que indica mayor fraccionamiento de plagioclasa en la fuente de las riolitas.

El patrón de una de las muestras de riolitas (IGM900916_JGB-469) exhibe anomalía negativa de Ce, que puede deberse a intemperismo de las rocas. Malpas et al. (2001) demuestran que el aumento del grado de meteorización o intemperismo implica incremento en la anomalía de Ce.
Tabla 6. Resultados de elementos traza y tierras raras (en ppm) en rocas de las Riolitas del Alto Los Cacaos y en dique de dacita. Valores de normalización de McDonough y Sun (1995)

\begin{tabular}{|c|c|c|c|c|}
\hline IGM & 900876 & 900916 & $900877^{\not 口}$ & LD \\
\hline $\mathrm{Li}$ & 15,01 & 14,44 & 23,58 & 0,50 \\
\hline $\mathrm{Be}$ & 3,23 & 4,91 & 2,59 & 0,10 \\
\hline Sc & 5,89 & 7,77 & 6,08 & 0,10 \\
\hline v & 3,55 & 5,75 & 31,10 & 0,20 \\
\hline $\mathrm{Cr}$ & $<0,5$ & 0,48 & 4,56 & 0,50 \\
\hline Co & 14,00 & 13,51 & 21,48 & 0,80 \\
\hline $\mathrm{Ni}$ & 1,91 & 3,93 & 18,67 & 0,50 \\
\hline $\mathrm{Cu}$ & 5,01 & 4,47 & 6,37 & 1,00 \\
\hline $\mathrm{Zn}$ & 16,74 & 17,27 & 55,53 & 4,00 \\
\hline $\mathrm{Ga}$ & 13,69 & 15,33 & 22,10 & 0,20 \\
\hline As & 2,36 & 1,45 & 2,49 & 0,40 \\
\hline $\mathrm{Rb}$ & 187,26 & 211,04 & 140,82 & 0,20 \\
\hline $\mathrm{Sr}$ & 64,74 & 60,02 & 406,63 & 1,00 \\
\hline $\mathrm{Cd}$ & 0,12 & 0,13 & 0,13 & 0,08 \\
\hline In & 0,01 & 0,04 & 0,05 & 0,01 \\
\hline Cs & 1,59 & 1,83 & 1,85 & 0,10 \\
\hline $\mathrm{Ba}$ & 625,42 & 706,72 & $1.762,99$ & 1,00 \\
\hline $\mathrm{TI}$ & 1,29 & 1,49 & 0,99 & 0,01 \\
\hline $\mathrm{Pb}$ & 13,86 & 12,08 & 14,15 & 2,00 \\
\hline $\mathrm{Bi}$ & 0,34 & 0,61 & 0,43 & 0,10 \\
\hline Th & 22,79 & 25,67 & 20,23 & 0,10 \\
\hline U & 4,52 & 6,34 & 3,82 & 0,00 \\
\hline $\mathrm{Zr}$ & 81,80 & 77,40 & 217,80 & 2,00 \\
\hline $\mathrm{Nb}$ & 18,80 & 20,90 & 16,10 & 2,00 \\
\hline $\mathrm{Ta}$ & $<7$ & $<7$ & $<7$ & 7,00 \\
\hline W & 53,30 & 40,50 & 76,10 & 8,00 \\
\hline $\mathrm{Hf}$ & $<8$ & $<8$ & $<8$ & 8,00 \\
\hline La & 32,37 & 29,29 & 64,49 & 0,10 \\
\hline $\mathrm{Ce}$ & 59,60 & 37,89 & 116,17 & 0,10 \\
\hline $\operatorname{Pr}$ & 7,80 & 7,95 & 12,68 & 0,10 \\
\hline $\mathrm{Nd}$ & 24,88 & 24,47 & 39,75 & 0,10 \\
\hline $\mathrm{Sm}$ & 4,61 & 5,54 & 6,14 & 0,01 \\
\hline Eu & 0,67 & 0,85 & 1,50 & 0,01 \\
\hline Gd & 3,45 & 3,95 & 4,67 & 0,01 \\
\hline $\mathrm{Tb}$ & 0,63 & 0,88 & 0,75 & 0,01 \\
\hline Dy & 3,62 & 5,26 & 3,57 & 0,01 \\
\hline Ho & 0,73 & 1,14 & 0,67 & 0,01 \\
\hline $\mathrm{Er}$ & 2,55 & 3,67 & 2,17 & 0,01 \\
\hline $\mathrm{Tm}$ & 0,39 & 0,57 & 0,27 & 0,01 \\
\hline $\mathrm{Yb}$ & 2,81 & 4,11 & 1,89 & 0,01 \\
\hline Lu & 0,43 & 0,65 & 0,27 & 0,01 \\
\hline$(\mathrm{La} / \mathrm{Yb})_{\mathrm{N}}$ & 7,71 & 4,77 & 22,88 & \\
\hline $\mathrm{Eu}_{\mathrm{N}} / \mathrm{Eu}^{*}$ & 0,51 & 0,56 & 0,86 & \\
\hline$(\mathrm{Gd} / \mathrm{Yb})_{\mathrm{N}}$ & 0,98 & 0,77 & 1,98 & \\
\hline
\end{tabular}

*Dique. LD: límite de detección. $\mathrm{Eu}_{\mathrm{N}} / \mathrm{Eu}^{*}$ : anomalía de Eu 


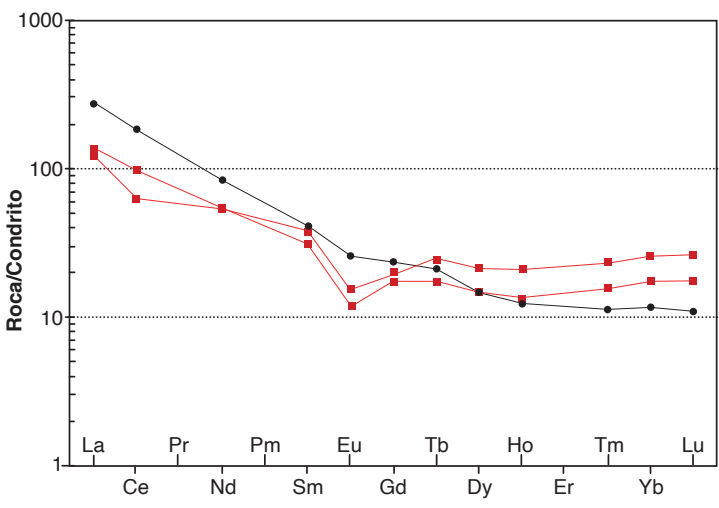

Figura 12. Patrón de elementos de las tierras raras normalizadas al condrito de McDonough y Sun (1995) correspondiente a las riolitas (cuadrados en rojo) de la unidad Riolitas del Alto Los Cacaos y a un dique de dacita (círculos negros) intrusivo en las riolitas

Los patrones en el diagrama multielemental de las tres muestras (figura 13) exhiben anomalías negativas de Nb y Ti que indican un origen relacionado con subducción. Sin embargo, se aprecian diferencias entre los patrones de las riolitas y del dique dacítico. El patrón de este último no tiene anomalía de Ba, y las anomalías de La-Ce, Sr, Zr y Ti son menos pronunciadas que en las riolitas.

\section{Posición estratigráfica y edad}

Las Riolitas del Alto Los Cacaos, según Ward et al. (1973) y Ward et al. (1977) podrían ser parte del Granito de Pescadero. Sin embargo, los resultados geocronológicos obtenidos en esta investigación indican que las riolitas representan un evento magmático anterior al que dio origen al Granito de Pescadero. El cuerpo de riolitas es posterior a la Formación Floresta.

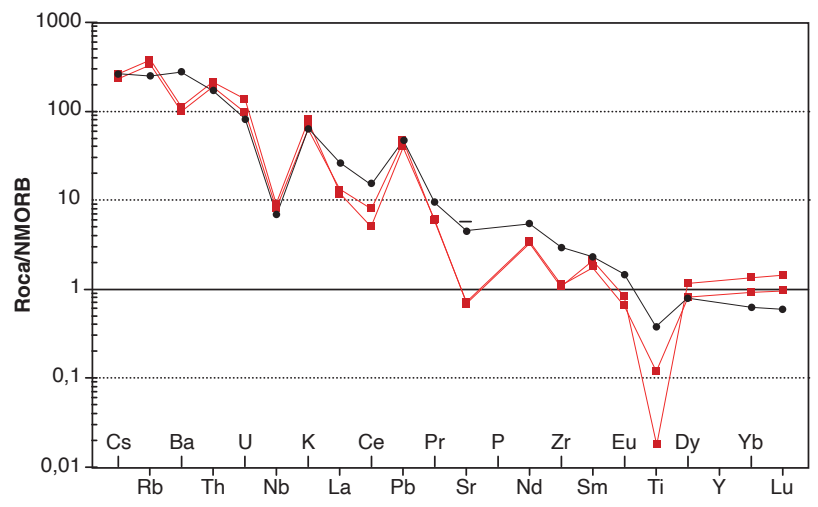

Figura 13. Diagrama de elementos traza normalizados al NMORB (Sun y McDonough, 1989) correspondiente a las riolitas (cuadrados en rojo) de la unidad Riolitas del Alto Los Cacaos y a un dique de dacita (círculos negros) intrusivo en las riolitas

De esta unidad no hay edades presentadas por autores anteriores. En este proyecto se analizaron por U/Pb los circones de la muestra AMC-0145, en el Laboratorio de Estudios Isotópicos del Centro de Geociencias de la Universidad Autónoma de México (UNAM), según metodología descrita en Solari et al. (2010). Con el fin de mejorar el rango de confiabilidad de la edad se realizó un filtro de los datos para descartar los circones con discordancias mayores al $10 \%$, de acuerdo con la relación $\left[{ }^{207} \mathrm{~Pb} /{ }^{235} \mathrm{U}\right)-\left({ }^{206} \mathrm{P}-\right.$ $\left.\mathrm{b} /{ }^{238} \mathrm{U} /{ }^{206} \mathrm{~Pb} /{ }^{238} \mathrm{U}\right)$ ] y se descartaron dos análisis que fueron rechazados desde el laboratorio. El cálculo de las edades se llevó a cabo usando el programa Isoplot/Ex 3.75-4.15 (Ludwig, 2012). Las edades reportadas $<800$ corresponden a las edades ${ }^{206} \mathrm{~Pb} / 2{ }^{238} \mathrm{U}$ Ma, mientras que las $>800 \mathrm{Ma}$ son las edades ${ }^{207} \mathrm{~Pb} /{ }^{206} \mathrm{~Pb}$. Los resultados se resumen en la tabla 7 y se hallan completos en el anexo A, y los datos de elementos de las tierras raras de los circones están en el anexo B.

Tabla 7. Resumen de las edades obtenidas en la muestra AMC-0145

\begin{tabular}{ccccccc}
\hline IGM & $\mathbf{N} .^{\circ}$ Campo & $\begin{array}{c}\text { Coordenada } \\
\text { N }\end{array}$ & $\begin{array}{c}\text { Coordenada } \\
\text { W }\end{array}$ & Clasificación & Edad U/Pb (Ma) & Edades heredadas \\
\hline \multirow{2}{*}{900876} & \multirow{2}{*}{ AMC-0145 } & 1203442 & 1132810 & Traquita de feldespato alcalino & $201,6 \pm 2,1$ & $\left(\begin{array}{c}1681 \pm 67, \mathrm{n}=1 ; 464 \pm 4,2, \mathrm{n}=1 ; 454 \pm 7,5, \mathrm{n}=1 ; 429 \pm 8,3, \mathrm{n}=1 ; \\
410 \pm 4,4, \mathrm{n}=1 ; 279 \pm 2,8, \mathrm{n}=1)\end{array}\right.$ \\
\hline
\end{tabular}

La muestra AMC-0145 fue colectada en la vía Mogotes-San Joaquín, al sur del Alto de Los Cacaos. Los circones de esta muestra son euhedrales prismáticos, principalmente cortos, aunque también los hay tabulares, muchos fracturados, de tonalidad rosa pálido. En general, son pequeños, menores de $50 \mu \mathrm{m}$, unos cuantos entre 50 y $100 \mu \mathrm{m}$ en su dimensión mayor, y solamente se observó un cristal de $400 \mu \mathrm{m}$ en su dimensión mayor, con pirámides bien desarrolladas, diferente de los otros cristales. En imágenes de catodoluminiscencia exhiben zonación entre sectorial y oscilatoria (figura 14). La muestra presenta circones heredados de $1700 \mathrm{Ma}, 464$, 454, 429, 410 y $279 \mathrm{Ma}$, y en el cristal mayor, que es diferente del resto de cristales, se obtuvo una edad de 150 
Ma concordante, que no es representativa, ya que este cristal puede deberse a contaminación de la muestra en alguna de las etapas del proceso de montaje, y por lo tanto dicha edad no se considera en la interpretación. Solamente se analizó un punto por cristal; por lo tanto, no es posible establecer si los componentes heredados en los circones corresponden a núcleos heredados o a cristales completos (xenocristales). El grupo más abundante de resultados se ubica en el Triásico tardío-Jurásico temprano, entre 213 y $190 \mathrm{Ma}$ (figuras 14 y 15), los cuales arrojan una edad promedio ponderada de 205,2 \pm 2 , 6 (figura 15B), con un MSWD=6,6. Este valor de MSWD es alto y sugiere la existencia de varias poblaciones de eda-

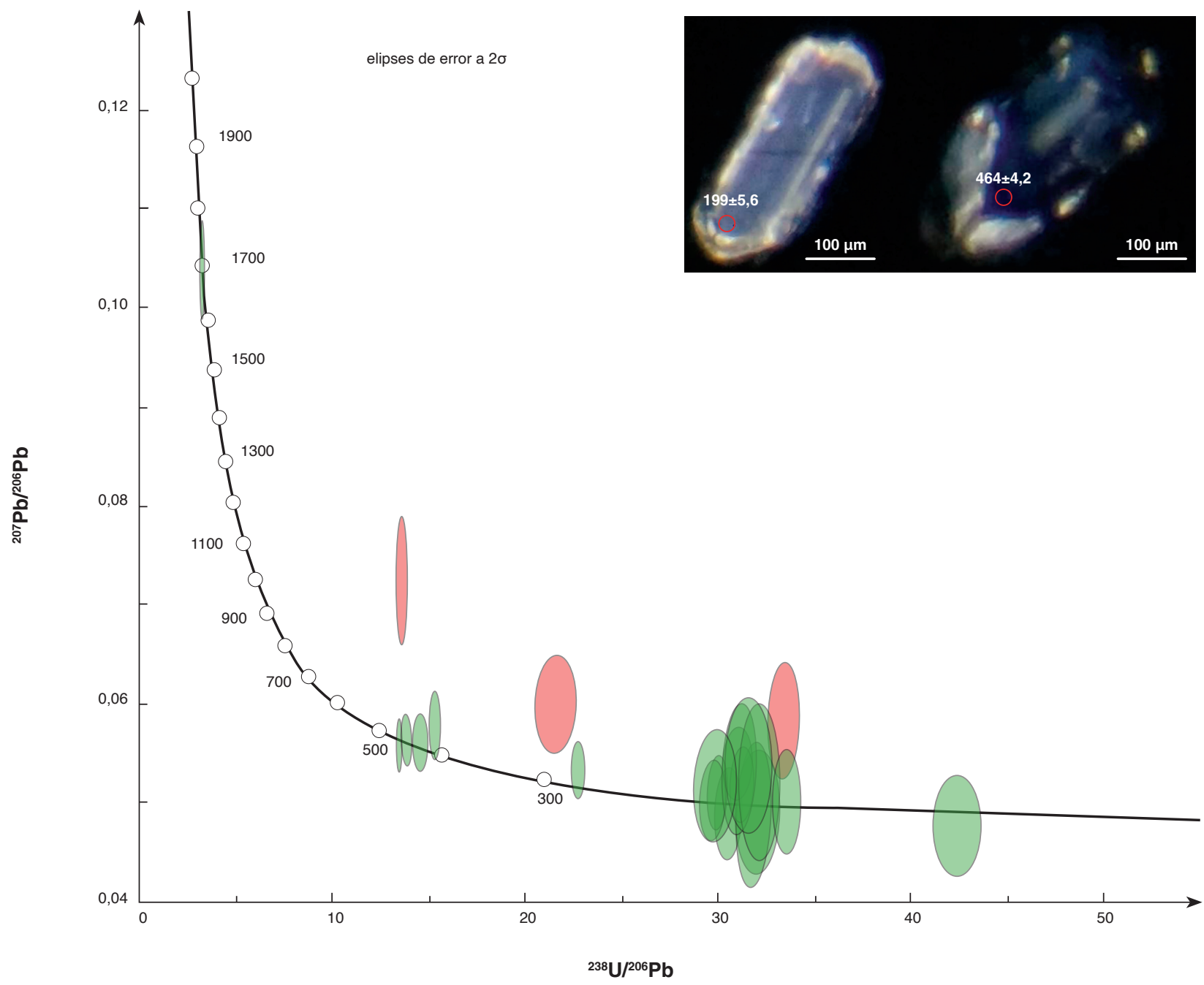

des en la muestra analizada. En la misma figura 15B es posible identificar que hay por lo menos dos poblaciones de edades: una integrada por la barra horizontal de color azul y la otra por la barra de color verde, que arrojaron las siguientes edades promedio ponderadas: la primera población arrojó una edad de 210,6 $\pm 2,7 \mathrm{Ma}$, con un MSWD de 1,8 (figura 16A), que puede corresponder a la edad de antecristales, es decir, a las primeras etapas de cristalización de los circones en la cámara magmática (Miller et al., 2007). La segunda población reveló una edad de 201,6 $\pm 2,1 \mathrm{Ma}$, con un MSWD de 2,3 (figura 16B), que corresponde a la de cristalización final de los circones en la roca.

Figura 14. Imágenes de catodoluminiscencia de circones representativos de la muestra AMC-0145 y diagrama de la concordia Tera-Wasserburg de todos los resultados de la muestra

En imágenes de CL: los números adyacentes a los círculos naranja representan edades en millones de años. En el diagrama de la concordia, las elipses rojas representan resultados descartados; las elipses verdes, análisis aceptados. 
A

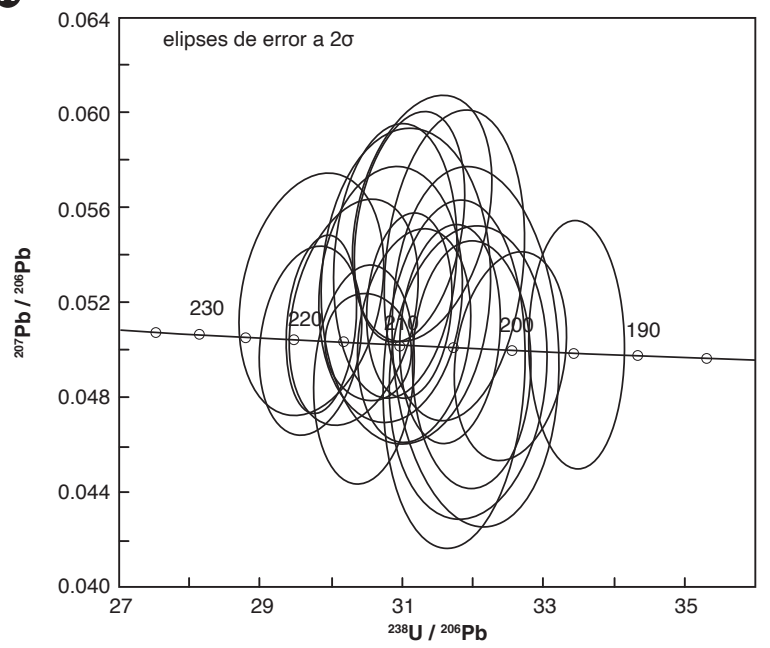

B

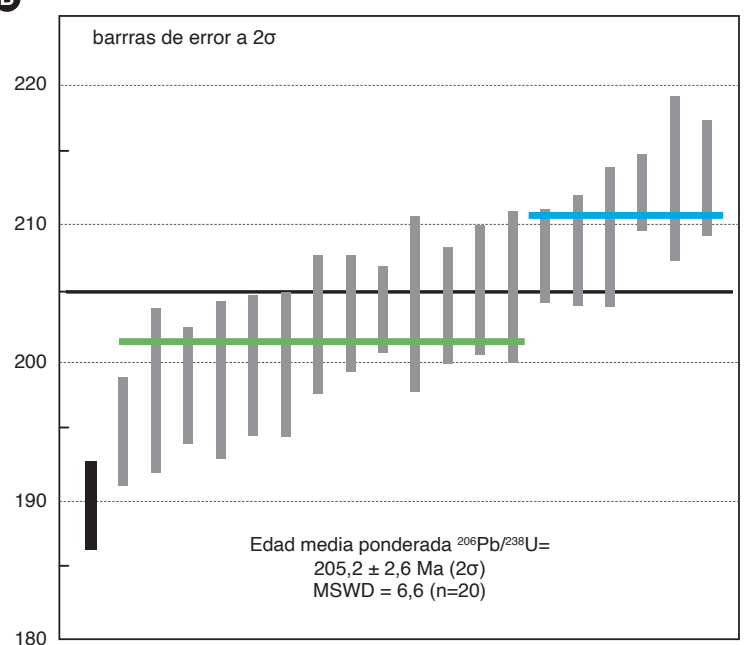

Figura 15. A). Concordia Tera-Wasserburg con resultados U/Pb en circón de entre 213 y 190 Ma de la muestra AMC-0145. B). Edad promedio ponderada de la muestra AMC-0145, barra negra: edad descartada del cálculo
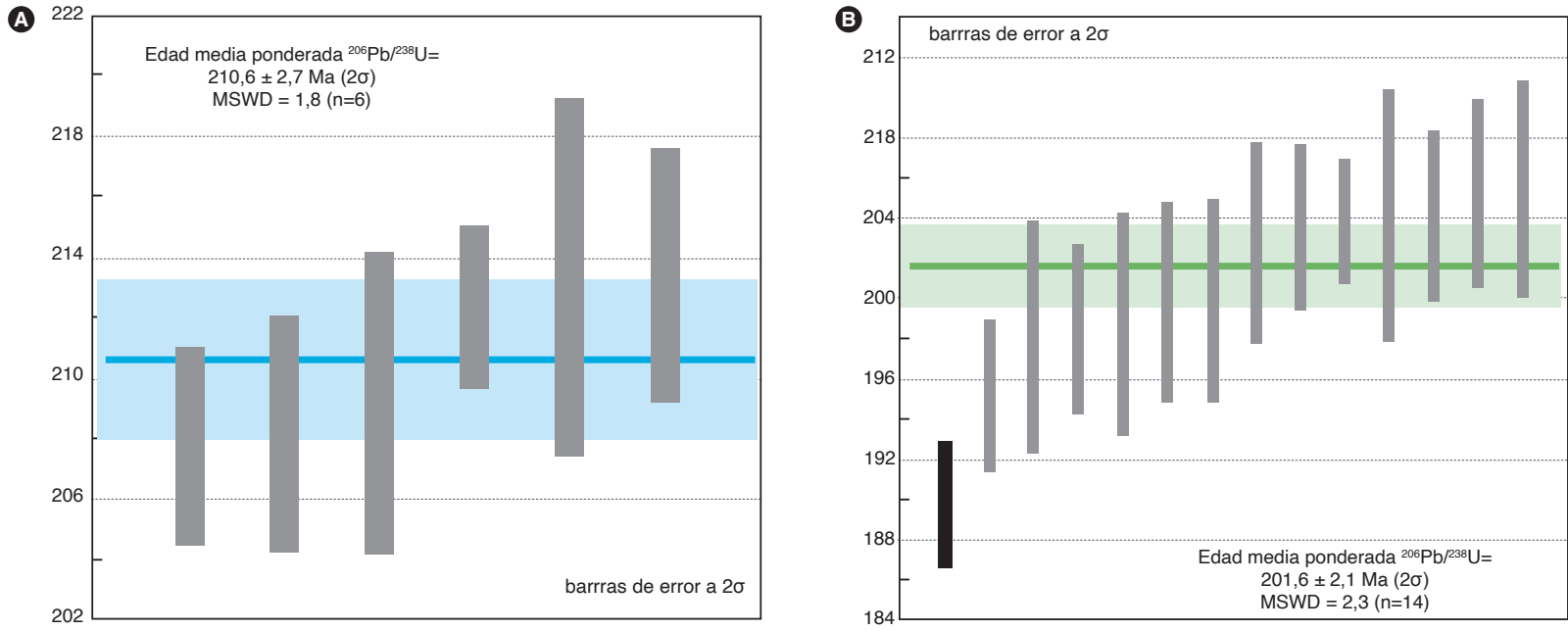

Figura 16. A). Edad promedio ponderada de antecristales en circones de la muestra AMC-0145. B) Edad promedio ponderada de cristalización final de circones en la muestra AMC-0145
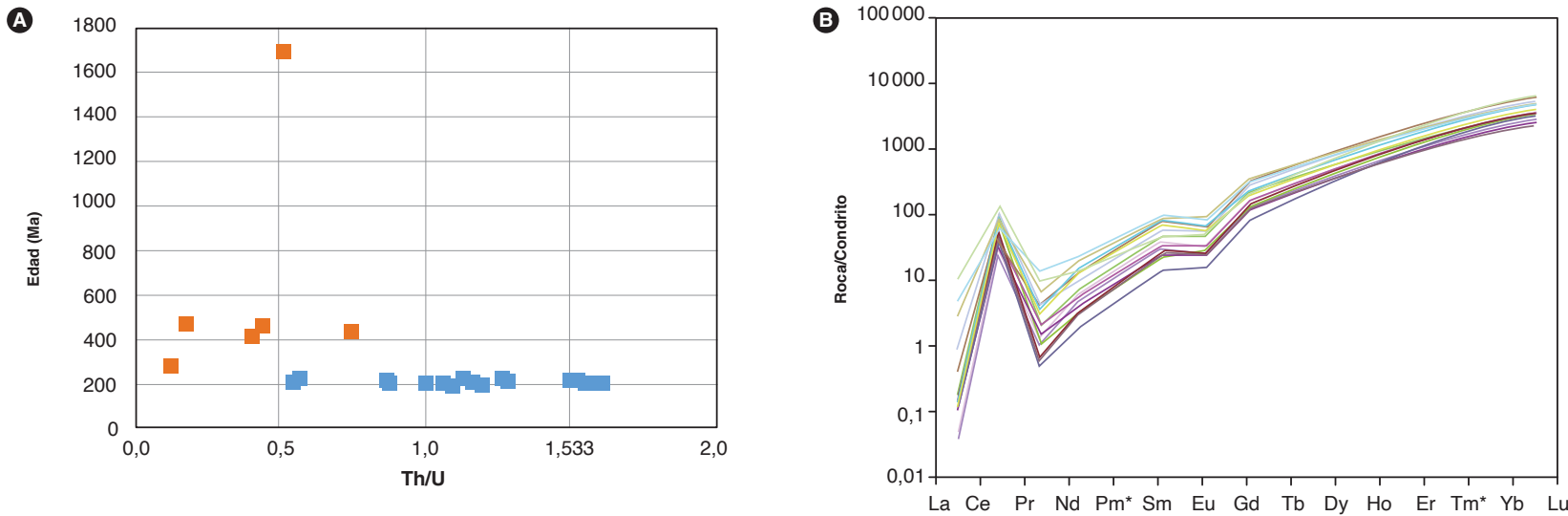

Figura 17. A). Diagramas de relación Th/U vs. edad en circones de la muestra AMC-0145. B). Patrones de REE de circones de la muestra AMC-0145 normalizados contra el condrito de McDonough y Sun (1995) 

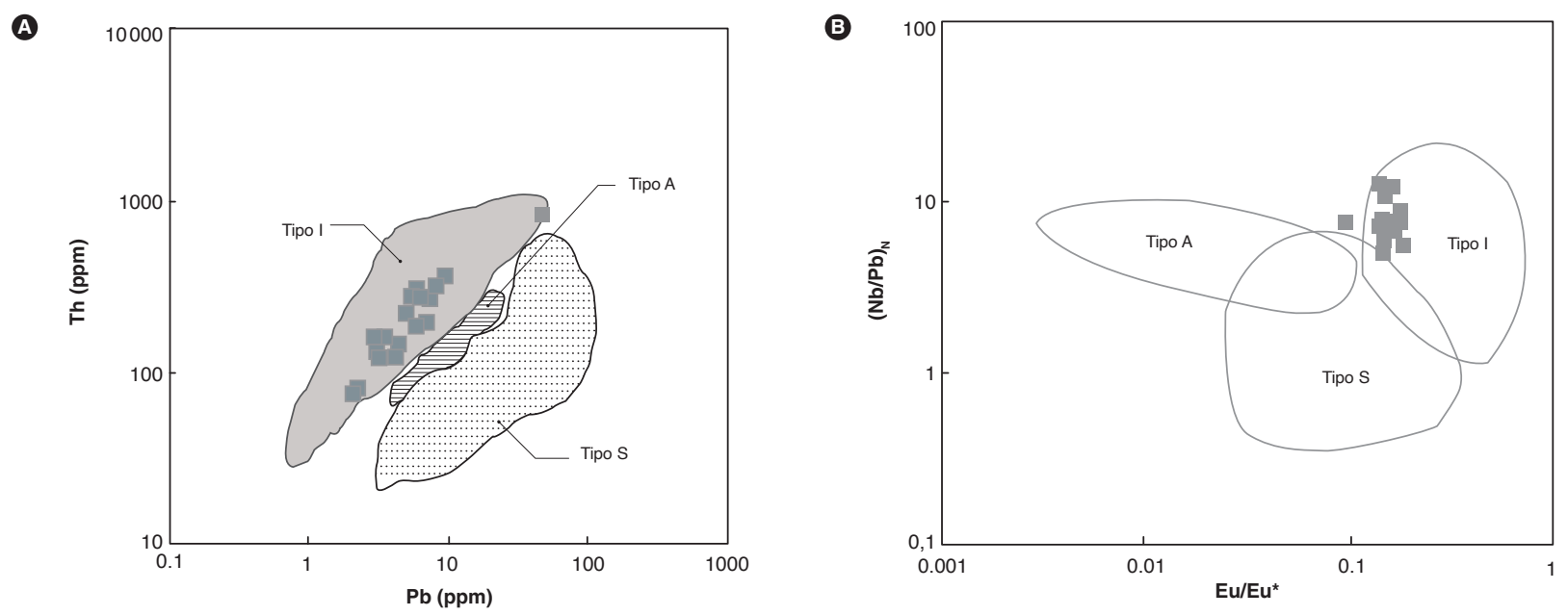

Figura 18. Diagramas de Wang et al. (2012) para inferir afinidad con tipo de fuentes magmáticas a partir de datos de circones de la muestra AMC-0145. A. $\mathrm{Pb}$ vs. Th. B. Eu/Eu* vs. $(\mathrm{Nb} / \mathrm{Pb})_{\mathrm{N}}$, donde $\mathrm{N}$ indica que fueron normalizados. Se usaron valores de normalización de Sun y McDonough (1989)

Los circones del Triásico tardío-Jurásico temprano presentan razones $\mathrm{Th} / \mathrm{U}$ por encima de 0,5 (figura $17 \mathrm{~A}$ ), comúnmente por encima de 1 , característica de circones ígneos (Rubatto, 2002). Sus patrones de REE son paralelos (figura 17B), con anomalía positiva de Ce y negativa de Eu, típicas de circones ígneos (Hoskin y Schaltegger, 2003). Aunque la anomalía de Eu no es muy pronunciada, origina un patrón semejante al de granitos tipo I (Wang et al., 2012).

Las concentraciones de $\mathrm{Pb}$ y Th en los circones (figura 18A) y las relaciones entre la anomalía de europio y la razón $(\mathrm{Nb} / \mathrm{Pb})$ normalizada (figura $18 \mathrm{~B})$ indican que la fuente de los circones fueron magmas tipo I.

\section{Correlación}

Las Riolitas del Alto Los Cacaos exhiben semejanzas geoquímicas (figuras 19 y 20) con las Riolitas de El Uvo (Zapata et al., 2018) y los granófidos del Granito de Pescadero (Zapata et al., 2017), y son más ácidas que las rocas de la Riolita de San Joaquín (Rodríguez et al., 2018) (figura 19). Con relación a los contenidos de elementos de las tierras raras, los patrones de las riolitas de la unidad Alto de Los Cacaos son paralelos con los de las Riolitas de El Uvo, mientras que son subparalelos con los patrones de los granófidos del Granito de Pescadero y con la Riolita de San Joaquín, ya que se cruza con los patrones de estas últimas en los HREE (figura 20). La composición de las Riolitas del Alto Los Cacaos es muy parecida a la de las Riolitas de El Uvo. Desde el punto de vista geocronológico, las Riolitas del Alto Los Cacaos tienen la misma edad de la Riolita de San Joaquín: 201,6 $\pm 2,1$ Ma las primeras, y 201,0 02,1 Ma las segundas. La edad mínima de las Riolitas de Los Cacaos (199,5 Ma) casi se traslapa con la máxima de las Riolitas de El Uvo (199 Ma). Ward et al. (1973) habían planteado que las rocas que en este trabajo se definieron como Riolitas del Alto de Los Cacaos hacían parte del Granito de Pescadero; no obstante, según los datos geocronológicos, las Riolitas del Alto Los Cacaos son más antiguas que las rocas subvolcánicas (granófidos) del Granito de Pescadero, las cuales arrojaron una edad de 192,9 $\pm 2 \mathrm{Ma}$, por lo tanto, las dos unidades no serían correlacionables en el tiempo.

Los tres cuerpos de riolitas - Alto de Los cacaos, San Joaquín y El Uvo- hacen parte del mismo arco magmático; el cuerpo de las Riolitas de El Uvo fue el último en formarse.

Las Riolitas del Alto de Los Cacaos son correlacionables en edad y composición con rocas de los plutones triásico-jurásicos del Macizo de Santander, principalmente con el Batolito de Mogotes, y con diques y cuerpos menores granofídicos que existen en los plutones. 


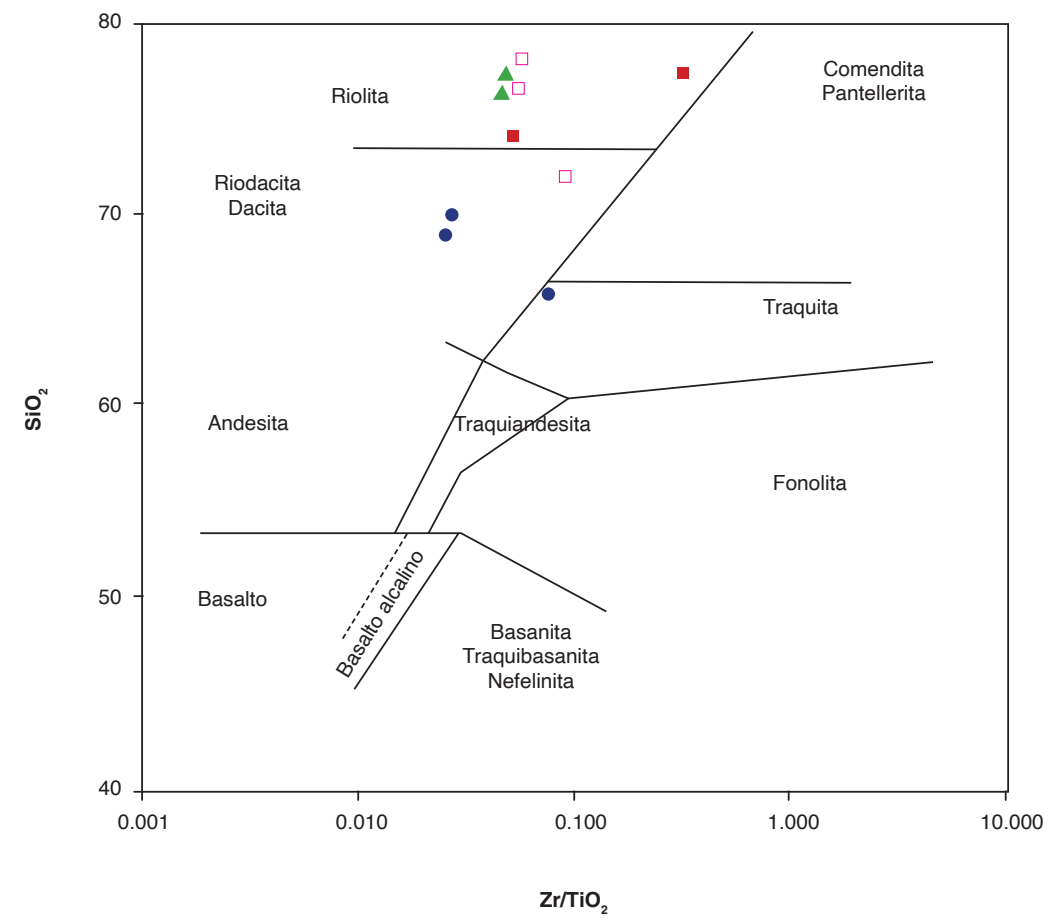

Figura 19. Diagrama de clasificación de Winchester y Floyd (1977) de las muestras de Riolitas del Alto Los Cacaos (cuadrados rojos rellenos), granófidos del Granito de Pescadero (cuadros magentas sin relleno), Riolitas de El Uvo (triángulos verdes) y Riolita de San Joaquín (círculos azules rellenos) Fuente de los datos: este trabajo; Zapata et al. (2017 y 2018); Rodríguez et al. (2018)

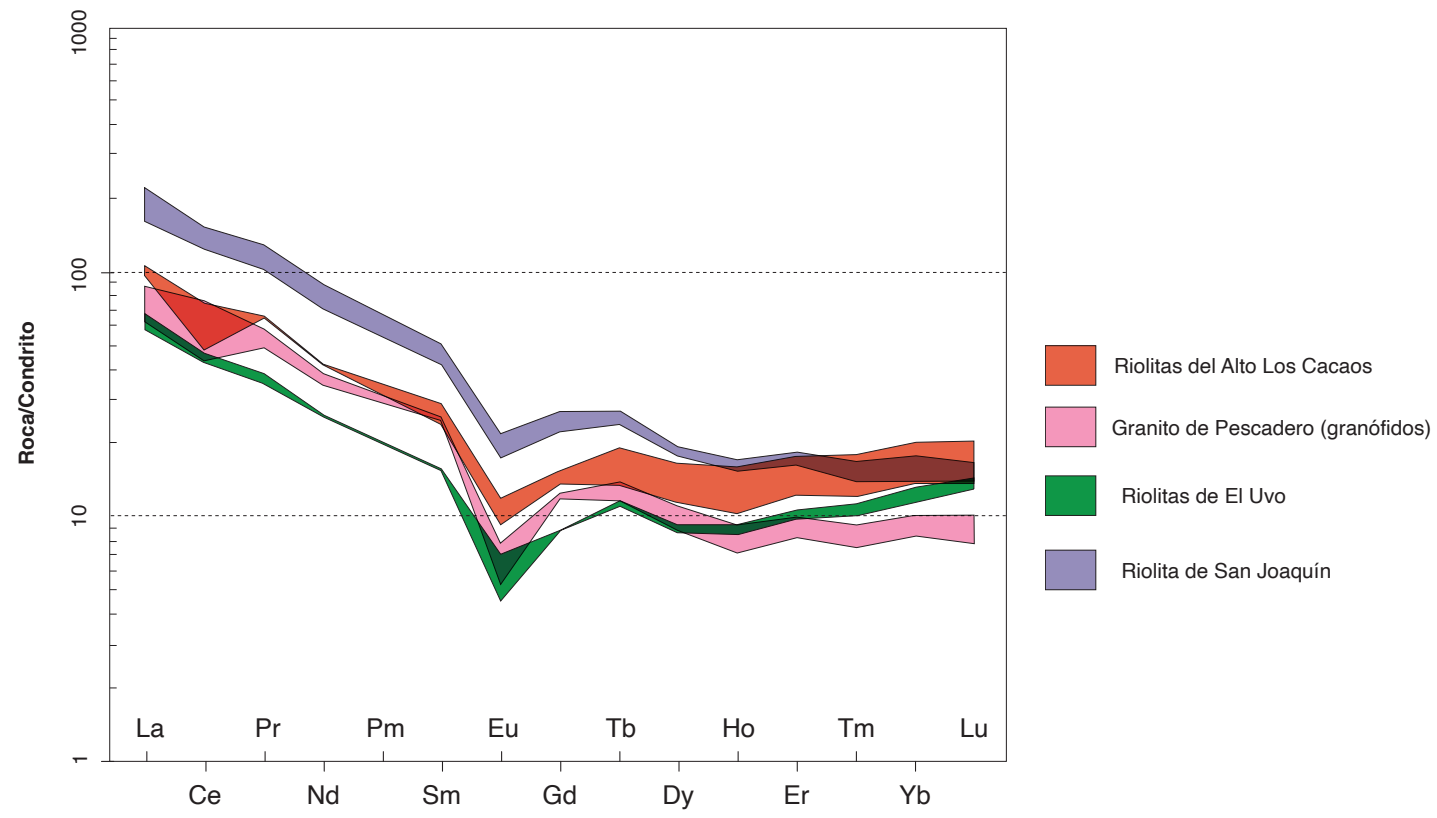

Figura 20. Comparación de los patrones de REE de muestras de las unidades Riolitas del Alto Los Cacaos, Granito de Pescadero, Riolitas de El Uvo y Riolita de San Joaquín. Gráfico normalizado a los valores de Boynton (1984)

Fuente de los datos: este trabajo; Zapata et al. (2017 y 2018); Rodríguez et al. (2018) 
El patrón de REE del dique de dacita es similar al de las granodioritas y de algunos monzogranitos del Batolito de Mogotes, lo cual podría indicar que el dique se originó en un pulso cogenético con los monzogranitos o granodioritas del plutón Batolito de Mogotes. En la figura 21 se presentan los patrones de algunas muestras del Batolito de Mogotes, cuyos datos fueron tomados de Correa Martínez et al. (2020) (muestras: IGM900874, 90091 7, 900900, 900902) y Van der Lelij (2013) (muestras 1 ODVL2 8 y 1 ODVL32).

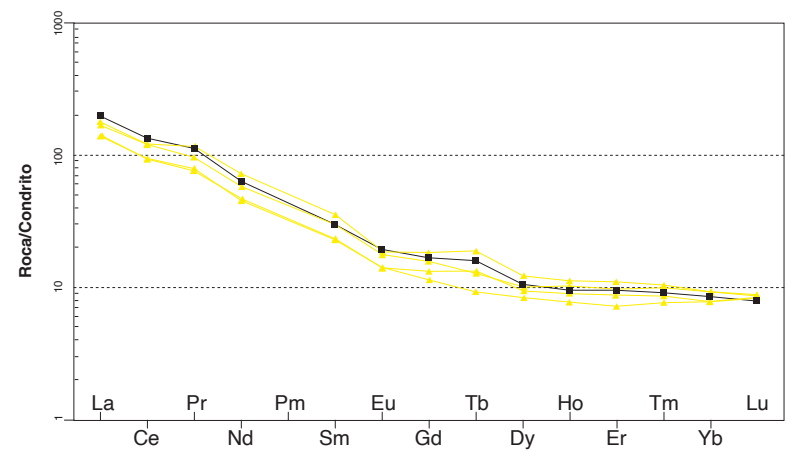

Figura 21. Patrones de REE del dique de dacita (IGM900877) intrusivo en las Riolitas del Alto Los Cacaos (cuadrado negro) y granodioritas y monzogranitos del Batolito de Mogotes (triángulos amarillos) Fuente de los datos de las muestras del Batolito de Mogotes: Correa Martínez et al. (2020); Van der Lelij (2013)

\section{Génesis}

La unidad Riolitas del Alto Los Cacaos corresponde a un cuerpo magmático hipoabisal generado en un ambiente relacionado a subducción, específicamente de arco continental (figuras 22 y 23), entre el Triásico tardío y el Jurásico temprano (ca. 203,7-199,5 Ma).

El dique que corta las riolitas también es de arco volcánico (figura 22) y posiblemente está relacionado con el emplazamiento de algunas rocas del Batolito de Mogotes, con las que guarda semejanzas químicas (figura 21).

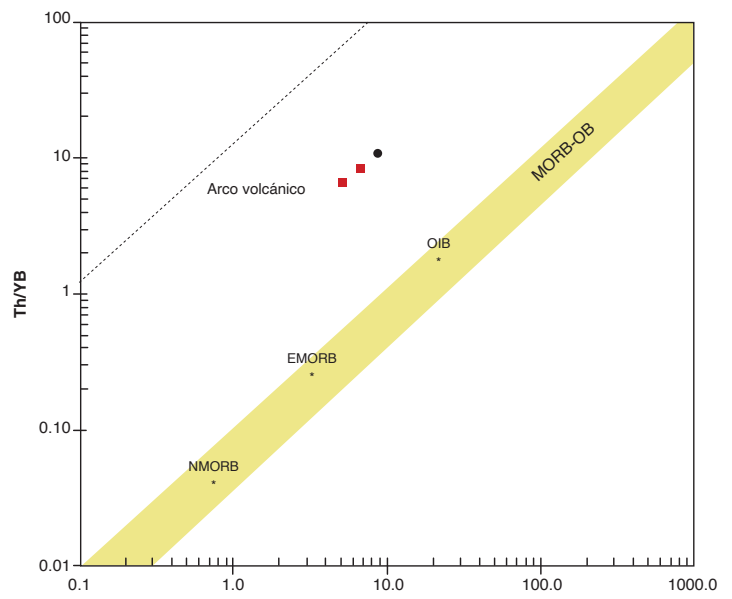

Figura 22. Diagrama de Pearce (2008) para discriminar el ambiente tectónico entre rocas de arco y rocas de corteza oceánica, correspondiente a muestras de las Riolitas del Alto Los Cacaos (cuadrados rojos) y del dique andesítico (círculo negro)

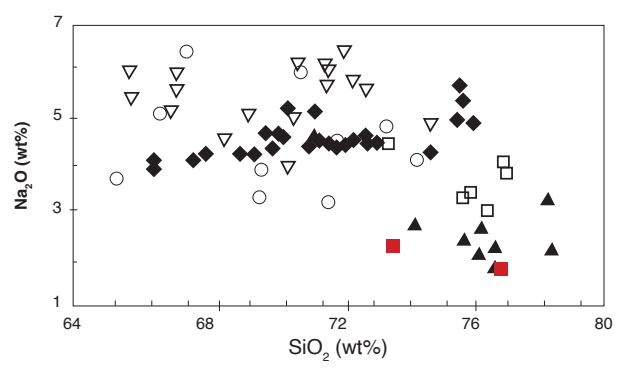

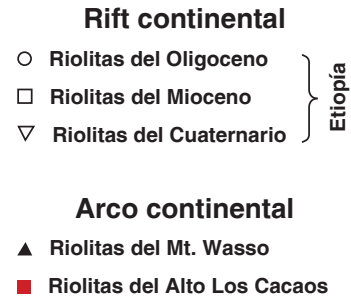

Arco de isla

- Riolitas de Izu-Bonin

Figura 23. Diagramas de variación de $\mathrm{SiO}_{2}$ vs. elemento mayor (A) y elemento traza (B). Comparación de las Riolitas del Alto Los Cacaos con riolitas de diversos ambientes, según datos recopilados y presentados por Ayalew e Ishiwatari (2011) 


\section{Recursos minerales}

La unidad Riolitas del Alto de Los Cacaos exhibe características petrográficas y geoquímicas que indican una alteración hidrotermal potásica que es corroborada por una anomalía de potasio detectada mediante gamaes- pectrometría (figura 24) en un estudio de exploración regional de minerales energéticos (Moreno et al., 201 1), llevado a cabo en el Macizo de Santander. La alteración potásica sugiere que la unidad tiene potencial de minerales metálicos.
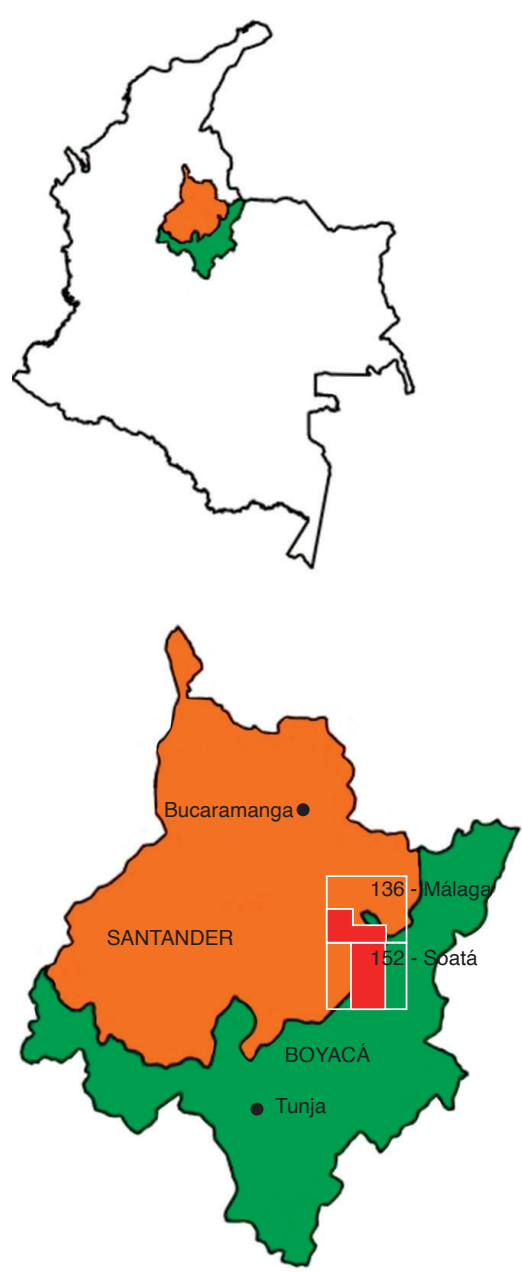

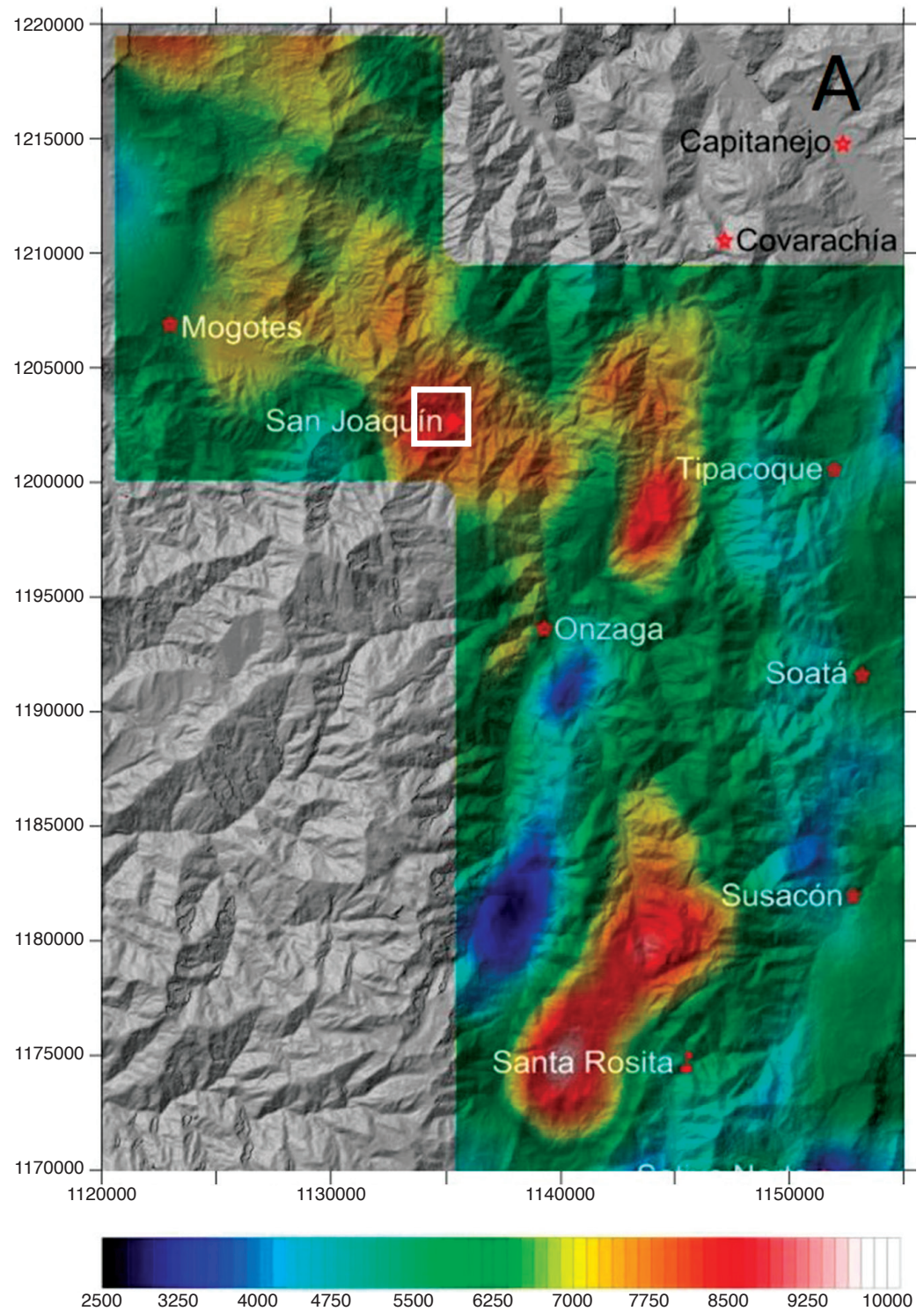

Figura 24. A). Distribución espacial de potasio en porcentaje. El recuadro blanco delimita el área de las Riolitas del Alto Los Cacaos, con anomalía de potasio en color gris 
Con el fin de evaluar el potencial mineral de la unidad se interpretaron algunos datos químicos, de las muestras de roca total y de los circones, que son reconocidos indicadores de fertilidad de las rocas. En el diagrama de $\mathrm{Rb}$ versus $\mathrm{Ba}$ (figura 25), adaptado por El-Sheshtawi et al., 1999) del diagrama original de Mason (1966) se aprecia que las muestras de riolitas corresponden a rocas fértiles (potencialmente mineralizadas), mientras que el dique que corta las riolitas grafica en el campo de los granitos estériles (no fértiles).

La composición de los circones permite distinguir entre suites magmáticas fértiles e infértiles, siendo la relación $\mathrm{Eu} / \mathrm{Eu}^{*}$ uno de los mejores indicadores de fertilidad. Específicamente, cuando esta relación es mayor de 0,3, indica una roca potencialmente fértil (Lu et al., 2016). Según el diagrama (Ce/Nd)/Y versus Eu/Eu* (figura 26), los circones de la muestra AMC-01 45 de las Riolitas del Alto de Los Cacaos, grafican en el campo de suites fértiles de sistemas de pórfidos $\mathrm{Cu} \pm \mathrm{Mo} \pm \mathrm{Au}$.

\section{Conclusiones}

La unidad Riolitas del Alto Los Cacaos es nombrada y definida en este trabajo como una nueva unidad en la geología del Macizo de Santander. Esta unidad está compuesta por riolitas y traquitas con texturas esferulítica, microporfídica y micrográfica con matriz felsítica, que afloran en el borde suroccidental del Batolito de Mogotes. Las rocas contienen feldespato potásico (ortosa), plagioclasa (albita), cuarzo y magnetita rica en titanio, y exhiben rasgos texturales y composicionales de meteorización y alteración hidrotermal.

Las Riolitas del Alto de Los Cacaos corresponden a un cuerpo ígneo subvolcánico generado a partir de un magma tipo I, potencialmente mineralizado, como un sistema de pórfido $\mathrm{Cu} \pm \mathrm{Mo} \pm \mathrm{Au}$.

El cuerpo Riolitas del Alto Los Cacaos se emplazó en el límite Triásico tardío-Jurásico temprano y tiene herencia del Paleoproterozoico, del Ordovícico, del Silúrico, del Devónico y del Pérmico.

La unidad Riolitas del alto Los Cacaos es más antigua que el Granito de Pescadero, y por lo tanto las dos unidades no son correlacionables. Es muy semejante geoquímicamente a las Riolitas de El Uvo y tiene igual edad que la Riolita de San Joaquín. Puede ser correlacionable con plutones, diques y cuerpos menores del Macizo de Santander, que se generaron al mismo tiempo.

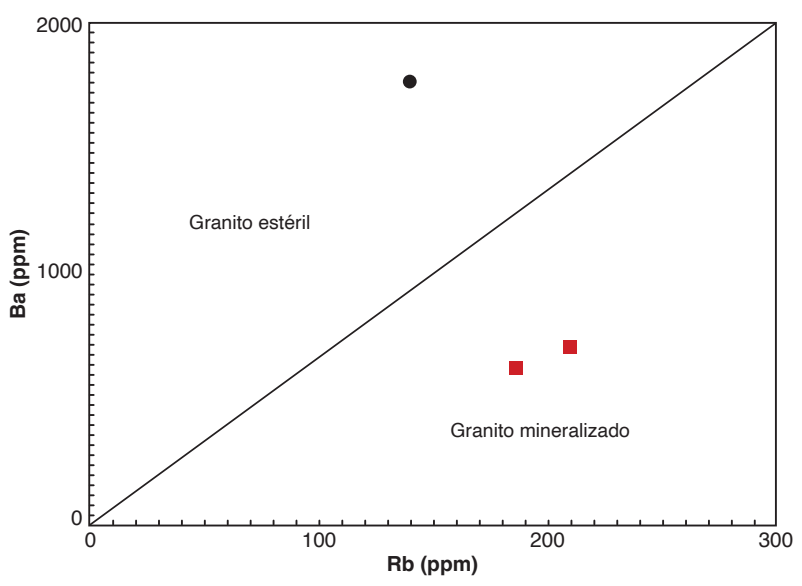

Figura 25. Diagrama de variación de Rb versus Ba en roca total (Mason, 1966, adaptado por El-Sheshtawi et al., 1999)

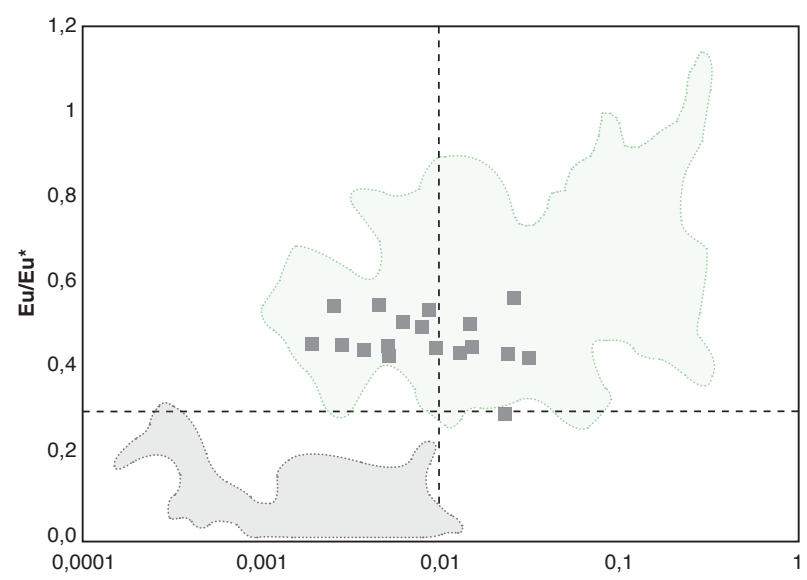

Figura 26. Composición de los circones de las Riolitas del Alto Los Cacaos (muestra AMC-0145) en diagrama de Lu et al. (2016), con campos de suites fértiles en verde claro, e infértiles en gris. Los valores de normalización usados para calcular Eu/Eu* son los de Sun y McDonough (1989)

\section{Referencias}

Ayalew, D. y Ishiwatari, A. (2011). Comparison of rhyolites from continental rift, continental arc and oceanic island arc: Implication for the mechanism of silicic magma generation. Island Arc, 20 (1), 78-93. https:// doi.org/10.1111/j.1440-1 738.2010.00746.x

Batchelor, R. A. y Bowden, P. (1 985). Petrogenetic interpretation of granitoid rock series using multicationic parameters. Chemical Geology, 48 (1-4), 43-55. https://doi.org/10.1016/0009-2541(85)90034-8

Boynton, W. V. (1984). Cosmochemistry of the rare earth elements: Meteorite studies. En Developments in geochemistry (vol. 2, pp. 63-114). Elsevier. 
Cardona, A. (2003). Correlações entre fragmentos do embasamento pre-Mesozoíco da terminação setentrional dos Andes colombianos, com base em dados isotópicos e geocronológicos (dissertação de mestrado). Universidade de São Paulo, Brazil.

Clavijo, J. (1994). Mapa geológico generalizado del departamento de Norte de Santander. Escala 1: 250.000. Memoria explicativa. Bucaramanga: Ingeominas.

Clavijo, J., Mantilla, F. L. C., Pinto, J., Bernal, L., Pérez, A. (2008). Evolución geológica de la serranía de San Lucas, norte del valle medio del Magdalena y noroeste de la cordillera Oriental. Boletín de Geología, 30 (1), 45-62.

Cordani, U. G., Cardona, A., Jiménez, D. M., Liu, D. y Nutman, A. P. (2005). Geochronology of Proterozoic basement inliers in the Colombian Andes: Tectonic history of remnants of a fragmented Grenville belt. Geological Society, London, Special Publications, 246, 329-346. https://doi.org/1 0.1 144/GSL.SP.2005.246.01.13

Correa Martínez, A. M., Rodríguez, G., Arango, M. I., Zapata, G. y Bermúdez J. G. (2020). Batolito de Mogotes. En Catálogo de las unidades litoestratigráficas de Colombia: Macizo de Santander. Vol. 1. Bogotá: Servicio Geológico Colombiano.

Droop, G. (1987). A general equation for estimating $\mathrm{Fe}^{3+}$ concentrations in ferromagnesian silicates and oxides from microprobe analyses, using stoichiometric criteria. Mineralogical Magazine, 51 (361), 431-435. https://doi.org/10.1180/minmag.1987.051.361.10

El-Sheshtawi, Y. A., Youssef, F., Ammar, F. A., Hassaan, M. M. y Sakr, S. M. (1999). Petrography and geochemistry of some granites and their metavolcanic country rocks in the Central Eastern Desert, Egypt. The proceeding of $1^{\text {st }}$ Seminar of Nuclear Raw Material and their Technology, Cairo, Egypt, 1-3.

Etayo Serna, F., Barrero, D., Lozano, H., Espinosa, A., González, H., Orrego, A., Ballesteros, I., Forero, H., Ramírez, C., Zambrano Ortiz, F., Duque Caro, H., Vargas, R., Núñez, A., Álvarez, J., Ropaín, C., Cardozo, E., Galvis, N., Sarmiento, L., Alberts, J. P., Case, J. E. et al. (1985). Mapa de terrenos geológicos de Colombia. Publicaciones Geológicas Especiales 14. Bogotá: Ingeominas.

Forero, A. (1990). The basement of the Eastern Cordillera, Colombia: An allochthonous terrane in northwestern South America. Journal of South American Earth Sciences, 3 (2-3), 141-151. https:/doi. org/10.1016/0895-9811(90)90026-W
García, C. y Ríos, C. (1999). Metamorfismo y metalogenia asociada del Macizo de Santander, cordillera Oriental, Colombia. Informe final Proyecto de investigación 1102-05-083-95. Bucaramanga: Colciencias y Universidad Industrial de Santander.

Goldsmith, R., Marvin, R. F. y Mehnert, H. H. (1971). Radiometric ages in the Santander Massif, Eastern Cordillera, Colombian Andes. U. S. Geological Survey Professional Paper 750-D, D44-D49.

Hoskin, P. W. y Schaltegger, U. (2003). The composition of zircon and igneous and metamorphic petrogenesis. Reviews in Mineralogy and Geochemistry, 53 (1), 27-62. https://doi.org/1 0.2113/0530027

Hughes, C. J. (1972). Spilites, keratophyres and the igneous spectrum. Geological Magazine, 109 (6),513-527. https://doi.org/10.1017/S0016756800042795

International Subcommision on Stratigraphic Classification. (1987). Stratigraphic classification and nomenclature of igneous and metamorphic rock bodies. GSA Bulletin, 99 (3), 440-442. https:/doi. org/10.1130/001 6-7606(1987)99<440:SCANOI $>2.0$. $\mathrm{CO} ; 2$

International Subcommision on Stratigraphic Classification. (1994). International Stratigraphic Guide: A guide to stratigraphic classification, terminology and procedure (2. ${ }^{\mathrm{a}}$ ed.). Amos Salvador (ed.). Internat. Union Geol. Sci. Trondheim \& Geol. Soc. Am. Boulder.

Irvine, T. N. y Baragar, W. R. A. (1971). A guide to the chemical classification of the common volcanic rocks. Canadian Journal of Earth Sciences, 8 (5), 523548. https://doi.org/10.1139/e71-055.

Janoušek, V., Farrow, C. M. y Erban, V. (2006). Interpretation of whole-rock geochemical data in igneous geochemistry: Introducing Geochemical Data Toolkit (GCDkit). Journal of Petrology, 47 (6), 1 255-1 259. https://doi.org/10.1093/petrology/egl013

Le Bas, M. J., Le Maitre, R. W., Streckeisen, A. y Zanettin, B. (1986). A chemical classification of volcanic rocks based on the total alkali-silica diagram. Journal of Petrology, 27 (3), 745-750. https://doi.org/10.1093/ petrology/27.3.745

Leal Mejía, H. (2011). Phanerozoic gold metallogeny in the Colombian Andes: A tectono-magmatic approach (Ph. D. thesis). Universitat de Barcelona.

Lu, Y. J., Loucks, R. R., Fiorentini, M., Mccuaig, T. C., Evans, N. J., Yang, Z. M., Hou, Z. Q., Kirkland, C. L., Parra 
Ávila, L. A. y Kobussen, A. (2016). Zircon compositions as a pathfinder for porphyry $\mathrm{Cu} \pm \mathrm{Mo} \pm \mathrm{Au}$ deposits. Society of Economic Geologists Special Publication, 19, 329-347. https://doi.org/1 0.5382/SP.19.13

Ludwig, K. R. (2012). User's manual for Isoplot 3.7 5-4.15: A geochronological toolkit Microsoft Excel. Berkeley Geochronology Center, special publication, 5.

Malpas, J., Duzgoren Aydin, N. S. y Aydin, A. (2001). Behaviour of chemical elements during weathering of pyroclastic rocks, Hong Kong. Environment International, 26 (5-6), 359-368. https://doi.org/10.1016/ S0160-41 20(01)00013-7

Mantilla, L. C., Bissig, T., Cottle, J. M. y Hart, C. J. (2012). Remains of early Ordovician mantle-derived magmatism in the Santander Massif (Colombian Eastern Cordillera). Journal of South American Earth Sciences, 38, 1-12. https://doi.org/10.1016/j. jsames.2012.03.001

Mantilla, L. C., Bissig, T., Valencia, V. y Hart, C. (2013). The magmatic history of the Vetas-California mining district, Santander Massif Eastern Cordillera, Colombia. Journal of South American Earth Sciences, 45, 235-249. https://doi.org/10.1016/j. jsames.2013.03.006

Mason, B. (1966). Principles of Geochemistry (3. ํ ed.). New York: John Wileys \& Sons.

McDonough, W. F. y Sun, S. S. (1995). The composition of the Earth. Chemical Geology, 120 (3-4), 223-253. https://doi.org/10.1016/0009-2541(94)00140-4

Miller, J. S., Matzel, J. E., Miller, C. F., Burgess, S. D. y Miller, R. B. (2007). Zircon growth and recycling during the assembly of large, composite arc plutons. Journal of Volcanology and Geothermal Research, 167 (1-4), 282-299. https://doi.org/10.1016/j.jvolgeores.2007.04.019

Moreno S., G., Díaz T., J. F. y Quintero O., F. A. (2011). Exploración de minerales energéticos a partir de mediciones gamaespectrométricas para potasio, uranio y torio en el sector central del Macizo de Santander, Colombia. Informe del Proyecto Exploración de Minerales Energéticos (Sub09-24). Bogotá: Servicio Geológico Colombiano,

Nakamura, N. (1 974). Determination of REE, Ba, Fe, Mg, $\mathrm{Na}$ and $\mathrm{K}$ in carbonaceous and ordinary chondrites. Geochimical et Cosmochimical Acta, 38 (5), 757-775. https://doi.org/10.1016/0016-7037(74)90149-5
Nesbitt, H. W. y Young, G. M. (1984). Prediction of some weathering trends of plutonic and volcanic rocks based on thermodynamic and kinetic considerations. Geochimica et Cosmochimica Acta, 48 (7), 1523-1534. https://doi.org/10.1016/0016-7037(84)90408-3

Ordóñez Carmona, O., Restrepo Álvarez, J. J. y Pimentel, M. M. (2006). Geochronological and isotopical review of pre-Devonian crustal basement of the Colombian Andes. Journal of South American Earth Sciences, 21 (4), 372-382. https://doi.org/10.1016/j. jsames.2006.07.005

Pearce, J. A. (2008). Geochemical fingerprinting of oceanic basalts with applications to ophiolite classification and the search for Archean oceanic crust. Lithos, 100 (1-4), 14-48. https://doi.org/10.1016/j. lithos.2007.06.016

Peccerillo, A. y Taylor, S. R. (1976). Geochemistry of Eocene calc-alkaline volcanic rocks from the Kastamonu area, Northern Turkey. Contributions to Mineralogy and Petrology, 58, 63-81. https:/doi. org/10.1007/BF00384745

Restrepo, J. J. y Toussaint, J. F. (1989). Terrenos alóctonos en los Andes colombianos: explicación de algunas paradojas geológicas. Memorias V Congreso Colombiano de Geología, tomo I, 92-107. Bucaramanga.

Restrepo Pace, P., Ruiz, J., Gehrels, G. y Cosca, M. (1997). Geochronology and Nd isotopic data of the Grenville-age rocks in the Colombian Andes: New constraints for Late Proterozoic-early Paleozoic paleocontinental reconstructions of the Americas. Earth and Planetary Science Letters, 150 (3-4), 427-441. https://doi.org/10.1016/S001 2-821X(97)00091-5

Restrepo Pace, P. A. (1995). Late Precambrian to early Mesozoic tectonic evolution of the Colombian Andes, based on new geochronological, geochemical and isotopic data (Ph. D. thesis). University of Arizona.

Ríos, C., García, C. y Takusa, A. (2003). Tectono-metamorphic evolution of the Silgara Formation metamorphic rocks in the southwestern Santander Massif, Colombian Andes. Journal of South American Earth Sciences, 16 (2), 133-154. https:/doi. org/10.1016/S0895-9811(03)00025-7

Rodríguez, G., Arango, M. I., Correa Martínez, M., A. M. y Zapata, G. (2020). Riolita de San Joaquín. En Catálogo de las unidades litoestratigráficas de Colombia: Macizo de Santander. Vol. 1. Bogotá: Servicio Geológico Colombiano. 
Rubatto, D. (2002). Zircon trace element geochemistry: Partitioning with garnet and the link between $\mathrm{U} / \mathrm{Pb}$ ages and metamorphism. Chemical Geology, 184 (1-2), 123-138. https://doi.org/10.1016/S0009$2541(01) 00355-2$

Schäfer, J., Grösser, J. y Rodríguez, G. (1998). Proterozoic Formación Silgará, cordillera Oriental, Colombia: Metamorphism and geochemistry of amphibolites. Zentralblatt für Geologie und Paläontologie, Teil I, 1997 (3-6), $531-546$.

Shand, S. J. (1943). Eruptive rocks: Their genesis, composition, classification, and their relation to ore-deposits with a chapter on meteorite. New York: John Wiley \& Sons.

Siivola, J. y Schmid, R. (2007). List of mineral abbreviations. En D. Fettes y J. Desmons (eds.), Metamorphic rocks: A classification and glossary of terms. Recommendations of the International Union of Geological Sciences Subcommission on the Systematics of Metamorphic Rocks (pp. 93-110). Cambridge: Cambridge University Press.

Smith, J. V. y Brown, W. L. (1988). Feldspar minerals. I. Crystal structures, physical, chemical and microtextural properties ( $2{ }^{\mathrm{a}}$ ed.). Berlin: Springer-Verlag.

Solari, L., Gómez Tuena, A., Bernal, J., Pérez Arvizu, O. y Tanner, M. (2010). U/Pb zircon geochronology with an integrated LA-ICP-MS microanalytical workstation: Achievements in precision and accuracy. Geostandards and Geoanalytical Research, 34 (1), 5-18. https://doi.org/10.1111/j.1 751-908X.2009.00027.x

Streckeisen, A. (1978). IUGS Subcommission on the Systematics of Igneous Rocks: Classification and nomenclature of volcanic rocks, lamprophyres, carbonatites and melilitic rocks; recommendation and suggestions. Neues Jahrbuch für Mineralogie, Abhandlungen, 134, 1-14.

Sun, S. S. y McDonough, W. S. (1989). Chemical and isotopic systematics of oceanic basalts: Implications for mantle composition and processes. Special Publications 42. London: Geological Society. https://doi. org/10.1144/GSL.SP.1 989.042.01.19

Urueña Suárez, C. L. (2014). Metamorfismo, exhumación y termocronología del Neis de Bucaramanga (Macizo de Santander, Colombia) (tesis de maestría). Universidad Nacional de Colombia.
Van der Lelij, R. (2013). Reconstructing North-Western Gondwana with implications for the evolution of the lapetus and Rheic Oceans: A geochronological, thermochronological and geochemical study (thése de doctorat). Université de Genève.

Van der Lelij, R., Spikings, R., Ulianov, A., Chiaradia, M. y Mora, A. (2016). Palaeozoic to Early Jurassic history of the northwestern corner of Gondwana, and implications for the evolution of the Iapetus, Rheic and Pacific Oceans. Gondwana Research, 31, 271-294. https://doi.org/10.1016/j.gr.2015.01.011

Vargas, R., Arias, A., Jaramillo, L. y Téllez, N. (1976). Geología del cuadrángulo I-13, Málaga. Bogotá: Ingeominas.

Vargas, R., Arias, A., Jaramillo, L. y Téllez, N. (1984). Geología de la plancha 136, Málaga. Mapa, escala: 1:100.000. Versión digital 2009. Bogotá: Ingeominas.

Wang, Q., Zhu, D. C., Zhao, Z. D., Guan, Q., Zhang, X. Q., Sui, Q. L., Chu Hu, Z. y Mo, X. X. (2012). Magmatic zircons from I-, S- and A- type granitoids in Tibet: Trace element characteristics and their application to detrital zircon provenance study. Journal of Asian Earth Sciences, 53, 59-66. https://doi.org/10.1016/j. jseaes.2011.07.027

Ward, D., Goldsmith, R., Cruz, J. y Restrepo, A. (1973). Geología de los cuadrángulos H-12, Bucaramanga, y H-13, Pamplona, Departamento de Santander. Boletín Geológico, 21 (1-3), 1-132.

Ward, D. E., Goldsmith, R., Cruz, J., Téllez, N. y Jaramillo, L. (1977). Mapa geológico de San Gil y Málaga (parte de los cuadrángulos I-12 y I-13), Colombia. Escala 1:100.000. Bogotá: Ingeominas.

Winchester, J. A. y Floyd, P. A. (1977). Geochemical discrimination of different magma series and their differentiation products using immobile elements. Chemical Geology, 20, 325-343. https://doi. org/10.1016/0009-2541(77)90057-2

Zapata, G., Correa Martínez, A. M., Rodríguez, G. y Arango, M. I. (2020). Granito de Pescadero. En Catálogo de las unidades litoestratigráficas de Colombia: Macizo de Santander. Vol. 1. Bogotá: Servicio Geológico Colombiano.

Zapata, G., Arango, M. I., Correa Martínez, A. M. y Rodríguez, G. (2020). Riolitas El Uvo. En Catálogo de las unidades litoestratigráficas de Colombia: Macizo de Santander. Vol. 1. Bogotá: Servicio Geológico Colombiano. 


\section{ANEXO A.}

Resultados isotópicos U/Pb en circón de la muestra AMC-0145

\begin{tabular}{|c|c|c|c|c|c|c|c|c|c|c|c|c|c|c|c|c|}
\hline $\begin{array}{c}\text { Punto } \\
\text { analizado }\end{array}$ & $\underset{(p p m)}{U}$ & $\begin{array}{c}\text { Th } \\
(\mathrm{ppm})\end{array}$ & $\Gamma h / U$ & ${ }^{207} \mathrm{~Pb} /{ }^{206} \mathrm{~Pb}$ & $\begin{array}{l} \pm 2 \sigma \\
\text { abs }\end{array}$ & ${ }^{207} \mathrm{~Pb} /{ }^{235} \mathrm{U}$ & $\pm 2 \sigma$ abs & ${ }^{206} \mathrm{~Pb} /{ }^{238} \mathrm{U}$ & $\pm 2 \sigma$ abs & $\begin{array}{c}\text { Correlación } \\
\text { errores }\end{array}$ & $\begin{array}{c}{ }^{206} \mathrm{~Pb} /{ }^{2384} \\
\mathrm{Edad}(\mathrm{Ma})\end{array}$ & $\pm 2 \sigma$ abs & $\begin{array}{c}{ }^{207} \mathrm{~Pb} /{ }^{235} \mathrm{U} \\
\mathrm{Edad}(\mathrm{Ma})\end{array}$ & $\pm 2 \sigma$ & $\begin{array}{l}{ }^{207} \mathrm{~Pb} /{ }^{206} \mathrm{~Pb} \\
\mathrm{Edad}(\mathrm{Ma})\end{array}$ & $\pm 2 \sigma$ \\
\hline Zircon- $042^{\star *}$ & 484 & 183 & 0,38 & 0,0583 & 0,0029 & 0,3860 & 0 & 0,04 & 0,00 & 0,48 & & & 331 & 21 & 570 & 110 \\
\hline Zircon-048* & 285 & 167 & 0,59 & 0,0588 & 0,0047 & 0,4200 & 0,1500 & 0,0512 & 0,0096 & 0,37 & & & 355 & 75 & 570 & 130 \\
\hline Zircon-054* & 8.100 & 12.100 & 1,49 & 0,0928 & 0,0033 & 0,1836 & 0,0070 & 0,0143 & 0,0002 & 0,27 & & & 171,2 & 6 & 1.481 & 71 \\
\hline Zircon- $056^{\star *}$ & 138 & 86 & 0,62 & 0,0730 & 0,0048 & 0,7420 & 0,0530 & 0,0742 & 0,0013 & 0,11 & & & 569,0 & 31,0 & $1.020,0$ & 140,0 \\
\hline Circón-066** & 136 & 121 & 0,89 & 0,0569 & 0,0042 & 0,2420 & 0,0200 & 0,0300 & 0,0006 & 0,10 & & & 223,0 & 16,0 & 470,0 & 160,0 \\
\hline $\begin{array}{l}\text { Zircon-036 } \\
\text { AMC-0145 }\end{array}$ & 208 & 115 & 0,55 & 0,0473 & 0,0042 & 0,1560 & 0,0140 & 0,0237 & 0,0005 & 0,23 & 150,8 & 3,4 & 146,0 & 12,0 & 40,0 & 180,0 \\
\hline Zircon-050 & 178 & 213 & 1,20 & 0,0500 & 0,0047 & 0,2070 & 0,0180 & 0,0299 & 0,0005 & 0,23 & 189,8 & 3,1 & 190,0 & 15,0 & 200,0 & 190,0 \\
\hline Zircon-041 & 206 & 181 & 0,88 & 0,0495 & 0,0036 & 0,2110 & 0,0150 & 0,0308 & 0,0006 & 0,09 & 195,2 & 3,8 & 196,0 & 12,0 & 180,0 & 150,0 \\
\hline Zircon-040 & 68,8 & 73,4 & 1,07 & 0,0503 & 0,0062 & 0,2160 & 0,0280 & 0,0312 & 0,0009 & 0,32 & 198,1 & 5,8 & 203,0 & 24,0 & 150,0 & 250,0 \\
\hline Zircon-046 & 243 & 266 & 1,09 & 0,0484 & 0,0046 & 0,2130 & 0,0190 & 0,0313 & 0,0007 & 0,24 & 198,5 & 4,2 & 195,0 & 16,0 & 100,0 & 190,0 \\
\hline Zircon-065 & 101,5 & 118 & 1,16 & 0,0486 & 0,0052 & 0,2120 & 0,0220 & 0,0313 & 0,0009 & 0,17 & 198,8 & 5,6 & 196,0 & 18,0 & 100,0 & 220,0 \\
\hline Zircon-053 & 97 & 157 & 1,62 & 0,0478 & 0,0058 & 0,2130 & 0,0260 & 0,0315 & 0,0008 & 0,10 & 199,9 & 5,0 & 194,0 & 21,0 & 20,0 & 230,0 \\
\hline Zircon-052 & 142 & 144 & 1,01 & 0,0531 & 0,0052 & 0,2330 & 0,0230 & 0,0315 & 0,0008 & 0,08 & 200,0 & 5,1 & 211,0 & 19,0 & 310,0 & 200,0 \\
\hline Zircon-045 & 171 & 273 & 1,60 & 0,0571 & 0,0044 & 0,2450 & 0,0180 & 0,0320 & 0,0008 & 0,03 & 202,8 & 5,0 & 222,0 & 15,0 & 440,0 & 170,0 \\
\hline Zircon-038 & 188 & 292 & 1,55 & 0,0490 & 0,0032 & 0,2240 & 0,0160 & 0,0321 & 0,0007 & 0,07 & 203,6 & 4,1 & 204,0 & 13,0 & 170,0 & 150,0 \\
\hline Zircon-059 & 297 & 353 & 1,19 & 0,0511 & 0,0032 & 0,2300 & 0,0140 & 0,0321 & 0,0005 & 0,14 & 203,9 & 3,1 & 212,0 & 12,0 & 240,0 & 130,0 \\
\hline Zircon-037 & 73,3 & 78,3 & 1,07 & 0,0511 & 0,0050 & 0,2340 & 0,0250 & 0,0322 & 0,0010 & 0,26 & 204,2 & 6,3 & 211,0 & 21,0 & 200,0 & 200,0 \\
\hline Zircon-060 & 270 & 315 & 1,17 & 0,0556 & 0,0036 & 0,2450 & 0,0170 & 0,0322 & 0,0007 & 0,00 & 204,2 & 4,2 & 222,0 & 14,0 & 400,0 & 130,0 \\
\hline Zircon-044 & 104,1 & 156 & 1,50 & 0,0546 & 0,0047 & 0,2400 & 0,0210 & 0,0324 & 0,0008 & 0,12 & 205,3 & 4,7 & 217,0 & 18,0 & 320,0 & 190,0 \\
\hline Zircon-055 & 178 & 274 & 1,54 & 0,0526 & 0,0046 & 0,2340 & 0,0200 & 0,0324 & 0,0009 & 0,21 & 205,6 & 5,4 & 212,0 & 17,0 & 240,0 & 180,0 \\
\hline Zircon-051 & 1.480 & 820 & 0,55 & 98 & 0,0019 & 64 & 096 & 28 & 05 & 0,50 & 207,8 & 3,3 & 201,2 & 7,6 & 176,0 & 87,0 \\
\hline Zircon-058 & 214 & 187 & 0,87 & 0,0486 & 0,0038 & 0,2220 & 0,0170 & 0,0328 & 0,0006 & 0,10 & 208,2 & 3,9 & 202,0 & 15,0 & 120,0 & 160,0 \\
\hline Zircon-039 & 97 & 126 & 1,30 & 0,0511 & 0,0040 & 0,2350 & 0,0170 & 0,0330 & 0,0008 & 0,03 & 209,2 & 5 & 213,0 & 14,0 & 290,0 & 150,0 \\
\hline Zircon-062 & 382 & 218 & 0,57 & 0,0509 & 0,0029 & 0,2360 & 0,0140 & 0,0335 & 0,0004 & 0,02 & 212,4 & 2,7 & 215,0 & 11,0 & 210,0 & 120,0 \\
\hline Zircon-049 & 187 & 213 & 1,14 & 0,0520 & 0,0038 & 0,2430 & 0,0190 & 0,0337 & 0,0009 & 0,11 & 213,4 & 5,9 & 220,0 & 16,0 & 300,0 & 150,0 \\
\hline Zircon-057 & 234 & 298 & 1,27 & 0,0503 & 0,0035 & 0,2340 & 0,0150 & 0,0337 & 0,0007 & 0,11 & 213,4 & 4,2 & 215,0 & 13,0 & 180,0 & 150,0 \\
\hline Zircon-063 & 920 & 122 & 0,13 & 0,0531 & 0,0021 & 0,3260 & 0,0140 & 0,0443 & 0,0005 & 0,29 & 279,1 & 2,8 & 287,0 & 11,0 & 322,0 & 88,0 \\
\hline $\begin{array}{l}\text { Zircon-067_ } \\
\text { AMC-0145 }\end{array}$ & 1.680 & 750 & 0,45 & 0,0555 & 0,0020 & 0,5670 & 0,0250 & 0,0730 & 0,0013 & 0,54 & 454,3 & 7,5 & 457,0 & 16,0 & 452,0 & 84,0 \\
\hline Zircon-043 & 1.570 & 1.180 & 0,75 & 0,0557 & 0,0021 & 0,5350 & 0,0240 & 0,0690 & 0,0014 & 0,37 & 429,9 & 8,3 & 435,0 & 15,0 & 436,0 & 75,0 \\
\hline Zircon-047 & 485 & 199 & 0,41 & 0,0575 & 0,0025 & 0,5250 & 0,0230 & 0,0657 & 0,0007 & 0,07 & 410,1 & 4,4 & 428,0 & 15,0 & 496,0 & 96,0 \\
\hline Zircon-061 & 962 & 175 & 0,18 & 0,0552 & 0,0020 & 0,5750 & 0,0230 & 0,0747 & 0,0007 & 0,30 & 464,1 & 4,2 & 461,0 & 15,0 & 417,0 & 81,0 \\
\hline Zircon-064 & 324 & 167 & 0,52 & 0,1031 & 0,0036 & 4,3700 & 0,1700 & 0,3043 & 0,0024 & 0,20 & $1.714,0$ & 12,0 & $1.706,0$ & 31,0 & $1.681,0$ & 67,0 \\
\hline
\end{tabular}

*Análisis descartados por el laboratorio. **Análisis descartados porque el porcentaje de discordancia es superior a 10 \%.

En negrita se destaca la mejor edad de cada análisis: edad 206Pb/238U. 
ANEXO B.

Resultados de elementos traza en los circones (en ppm) de la muestra AMC-0145

\begin{tabular}{|c|c|c|c|c|c|c|c|c|c|c|c|c|c|c|c|c|c|c|c|}
\hline $\begin{array}{c}\text { Punto } \\
\text { analizado }\end{array}$ & $\mathbf{P}$ & $\mathrm{Ti}$ & $\mathbf{Y}$ & $\mathrm{Nb}$ & La & $\mathrm{Ce}$ & $\mathrm{Pr}$ & Nd & $\mathrm{Sm}$ & Eu & Gd & Tb & Dy & Ho & $\mathrm{Er}$ & Yb & Lu & $\mathrm{Hf}$ & $\mathrm{Pb}$ \\
\hline $\begin{array}{l}\text { Zircon-036 } \\
\text { AMC-0145 }\end{array}$ & 204 & 6,83 & 974 & 2,34 & ND & 15,8 & 0,047 & 0,9 & 2,05 & 0,85 & 14 & 5,69 & 75,8 & 29,6 & 160 & 380 & 86,6 & 9510 & 4,77 \\
\hline Zircon-037 & 53 & 10,7 & 879 & 1,26 & 0,0114 & 22,1 & 0,145 & 2,64 & 5,41 & 1,67 & 24,1 & 7,58 & 91 & 30,5 & 142 & 276 & 57,1 & 8.870 & 2,3 \\
\hline Zircon-038 & 399 & 9,74 & 1.760 & 3,87 & 0,046 & 51,6 & 0,296 & 4,57 & 8,7 & 3,28 & 44,9 & 14,9 & 175 & 60,7 & 281 & 520 & 102,3 & 7.990 & 6,1 \\
\hline Zircon-039 & 260 & 10,2 & 1.290 & 1,49 & 0,034 & 22,7 & 0,306 & 4,58 & 7,1 & 2,25 & 34,3 & 10,8 & 122 & 42,4 & 203 & 390 & 78,4 & 7.630 & 3,2 \\
\hline Zircon-040 & 211 & 9,3 & 876 & 1,45 & ND & 23,2 & 0,121 & 2 & 4,05 & 1,32 & 21,3 & 6,86 & 81 & 28,6 & 140 & 275 & 57,1 & 8.980 & 2,13 \\
\hline Zircon-041 & 393 & 7,35 & 1.186 & 6,92 & 0,024 & 56,3 & 0,063 & 1,48 & 3,99 & 1,39 & 25,1 & 9,35 & 111,5 & 40,4 & 193 & 361 & 71,6 & 10.290 & 6 \\
\hline Zircon-042 & 530 & 8,14 & 1.680 & 8,08 & 0,138 & 27,5 & 0,148 & 3,07 & 5,72 & 0,84 & 29,3 & 10,9 & 143 & 54,4 & 279 & 634 & 133 & 10.800 & 21 \\
\hline Zircon-043 & 1.360 & 21,7 & 3.480 & 13 & 1,97 & 50,1 & 1,17 & 12,3 & 13,3 & 1,31 & 67,9 & 24,7 & 313 & 117 & 598 & 1.230 & 249 & 8.820 & 103 \\
\hline Zircon-044 & 260 & 10,3 & 1.640 & 1,84 & 0,03 & 34,6 & 0,447 & 7,11 & 12,1 & 3,74 & 52,7 & 15,7 & 175 & 59,2 & 254 & 453 & 87,1 & 8.480 & 3,43 \\
\hline Zircon-045 & 360 & 10,9 & 2.010 & 3,56 & 1,13 & 42,7 & 1,21 & 10,8 & 14,2 & 4,36 & 59,9 & 17,4 & 199 & 66,3 & 304 & 549 & 112 & 9.700 & 5,55 \\
\hline Zircon-046 & 720 & 15,2 & 2.210 & 7,25 & 2,4 & 75 & 0,85 & 6,5 & 7,1 & 2,5 & 40,7 & 14,8 & 189 & 72,1 & 363 & 732 & 150 & 10.000 & 7,50 \\
\hline Zircon-047 & 700 & 10,4 & 1.600 & 6 & 0,096 & 13,3 & 0,064 & 1,43 & 3,49 & 0,72 & 25,5 & 10,7 & 137 & 53,5 & 276 & 556 & 117 & 11.190 & 32,25 \\
\hline Zircon-048 & 224 & 7,8 & 1.120 & 5,8 & 0,73 & 38,2 & 0,43 & 3,6 & 4,8 & 1,28 & 18,4 & 7,7 & 87 & 35,1 & 164 & 347 & 73 & 11.300 & 12,73 \\
\hline Zircon-049 & 580 & 11,4 & 1.630 & 4,56 & 0,026 & 52,7 & 0,152 & 2,97 & 5,9 & 1,99 & 31,6 & 11,3 & 144 & 53,4 & 261 & 501 & 102 & 9.500 & 6,45 \\
\hline Zircon-050 & 563 & 11,81 & 1.640 & 5,53 & 0,086 & 61,8 & 0,35 & 4,66 & 8,12 & 3,01 & 42,1 & 13,2 & 156 & 56,7 & 267 & 506 & 102,6 & 8.740 & 5,10 \\
\hline Zircon-051 & 930 & 6,8 & 2.920 & 32,2 & 0,096 & 82,5 & 0,05 & 1 & 4,21 & 1 & 34,4 & 5 & 217 & 90,9 & 500 & 70 & 255 & 90 & 17,00 \\
\hline Zircon-052 & 333 & 11,1 & 1.080 & 3,09 & ND & 39,4 & 0,139 & 2,38 & 4,6 & 1,71 & 23,5 & 8,27 & 97,1 & 36,1 & 175 & 344 & 72,7 & 10.040 & 4,45 \\
\hline Zircon-053 & 308 & 10,9 & 1.340 & 2,04 & 0,031 & 35,2 & 0,32 & 5,7 & 9,8 & 6 & 41 & 12,3 & 143 & 45 & 215 & 373 & 77 & 9.010 & 3,00 \\
\hline Zircon-054 & 1.800 & 33,9 & 8.900 & 169 & 139 & 530 & 72 & 277 & 82 & 31,9 & 194 & 67,4 & 751 & 269 & 1330 & 2.440 & 475 & 10.900 & 119,75 \\
\hline Zircon-055 & 470 & 13,5 & 2.180 & 3,3 & 0,102 & 50,4 & 0,61 & 8,8 & 13,4 & 5,04 & 59,5 & 19,1 & 214 & 74,6 & 343 & 625 & 127 & 9.200 & 6,30 \\
\hline Zircon-056 & 20 & 15,3 & 890 & 2,59 & 0,43 & 11,3 & 0,184 & 2,29 & 2,66 & 0,255 & 17 & 6,19 & 81 & 28,9 & 144 & 270 & 53,1 & 9.100 & 10,13 \\
\hline Zircon-057 & 430 & 11,2 & 2.280 & 4,56 & 0,026 & 52,8 & 0,398 & 6,44 & 11,4 & 3,48 & 55,3 & 17,8 & 217 & 78,3 & 366 & 690 & 139 & 9.000 & 7,78 \\
\hline Zircon-058 & 330 & $9,0<$ & 1.090 & 5,04 & IND & 48,3 & 0,055 & 1,19 & 3,71 & 1 & 4 & 1,09 & 96,8 & 36,3 & 170 & 001 & 71,6 & 690 & 7,05 \\
\hline Zircon-059 & 320 & 8,63 & 1.150 & 5,01 & ND & 49,6 & 0,1 & 1,66 & 3,26 & 1,53 & 21,6 & 8,22 & 96,8 & 36,7 & 180 & 380 & 80,1 & 8.990 & 9,60 \\
\hline Zircon-060 & 434 & 10,7 & 1.990 & 5,62 & 0,21 & 58,2 & 0,361 & 5,56 & 9, & 2,96 & 4 & 16,3 & 189 & 69,3 & 318 & 617 & 121 & 9.070 & 8,45 \\
\hline Zircon-061 & 345 & 5,92 & 1.250 & 6,7 & 0,042 & 6,39 & 0,046 & 0,76 & 2,34 & 0,252 & 20,3 & 7,87 & 105,5 & 40,4 & 203 & 413 & 86,7 & 9.900 & 71,25 \\
\hline Zircon-062 & 520 & 13,4 & 1.640 & 15 & 0,64 & 38,5 & 0,54 & 6,2 & 7,9 & 2,22 & 36,7 & 12,7 & 154 & 56 & 265 & 512 & 104 & 10.700 & 13,35 \\
\hline Zircon-063 & 680 & 10 & 950 & 29,2 & $7, I$ & 21,5 & 2,84 & 17,9 & 0,3 & 1,06 & 21,6 & 6,64 & 82 & 31,1 & 159 & 378 & 83 & 11100 & 43,00 \\
\hline Zircon-064 & 580 & 8,9 & 1180 & 3,52 & 17,5 & 60 & 6 & 32 & 10,7 & 0,82 & 31,1 & 9,5 & 107,3 & 40,5 & 186 & 344 & 67,8 & 9380 & 99,50 \\
\hline Zircon-065 & 490 & 10,2 & 1320 & 2,61 & ND & 41,4 & 0,188 & 3,53 & 6,86 & 2,76 & 36,1 & 11,7 & 132 & 46,7 & 208 & 369 & 73,8 & 9730 & 3,25 \\
\hline Zircon-066 & 290 & 15,4 & 860 & 4,45 & 1,65 & 40,5 & 0,46 & 3,07 & 3,04 & 1,04 & 16,4 & 5,92 & 75 & 29,5 & 148 & 309 & 64,6 & 10600 & 4,28 \\
\hline $\begin{array}{l}\text { Zircon-067 } \\
\text { AMC-0145 }\end{array}$ & 1010 & 7,4 & 2900 & 7,9 & 0,13 & 15,5 & 0,274 & 4,51 & 11,4 & 1,17 & 66,8 & 24,2 & 286 & 101 & 445 & 763 & 145 & 11600 & 122,75 \\
\hline
\end{tabular}

